\title{
Evolution and systematics of Green Bush-crickets (Orthoptera: Tettigoniidae: Tettigonia) in the Western Palaearctic: testing concordance between molecular, acoustic, and morphological data
}

\author{
Beata Grzywacz ${ }^{1}$ - Klaus-Gerhard Heller ${ }^{2} \cdot$ Elżbieta Warchałowska-Śliwa $^{1}$ • \\ Tatyana V. Karamysheva ${ }^{3}$. Dragan P. Chobanov ${ }^{4}$
}

Received: 14 June 2016 / Accepted: 16 November 2016 / Published online: 8 December 2016

(C) The Author(s) 2016. This article is published with open access at Springerlink.com

\begin{abstract}
The genus Tettigonia includes 26 species distributed in the Palaearctic region. Though the Green Bush-crickets are widespread in Europe and common in a variety of habitats throughout the Palaearctic ecozone, the genus is still in need of scientific attention due to the presence of a multitude of poorly explored taxa. In the present study, we sought to clarify the evolutionary relationships of Green Bush-crickets and the composition of taxa occurring in the Western Palaearctic. Based on populations from 24 disjunct localities, the phylogeny of the group was estimated using sequences of the cytochrome oxidase subunit I (COI) and the internal transcribed spacers 1 and 2 (ITS1 and ITS2). Morphological and acoustic variation documented for the examined populations and taxa was interpreted in the context of phylogenetic relationships inferred from our genetic analyses. The trees generated in the present study supported the existence of three main lineages: "A"-composed of all sampled populations of Tettigonia viridissima and the Tettigonia vaucheriana complex, "B"-comprising Tettigonia caudata, Tettigonia uvarovi, and the Tettigonia armeniaca complex, and "C"consisting of Tettigonia cantans. The present study provides the first phylogenetic foundation for reviewing the systematics
\end{abstract}

Beata Grzywacz

grzywacz@isez.pan.krakow.pl

1 Institute of Systematics and Evolution of Animals, Polish Academy of Sciences, Sławkowska 17, 31-016 Krakow, Poland

2 Grillenstieg 18, 39120 Magdeburg, Germany

3 Institute of Cytology and Genetics of the Siberian Branch of the Russian Academy of Sciences, Novosibirsk, Russia

4 Institute of Biodiversity and Ecosystem Research, Bulgarian Academy of Sciences, 1 Tsar Osvoboditel Boul, 1000 Sofia, Bulgaria of Tettigonia (currently classified mostly according to morphological characteristics), proposing seven new synonymies.

Keywords Tettigonia $\cdot$ mtDNA · rDNA · Phylogeny · Bioacoustics

\section{Introduction}

Genus Tettigonia Linnaeus, 1758 presently includes 26 recognized species (Eades et al. 2016) distributed in the Palaearctic ecozone and belongs to the long-horned orthopterans or the bush-crickets (Ensifera, Tettigonioidea). Tettigonia, popularly known as the Green Bush-crickets, are generally large green orthopterans with moderately slender body and legs and welldeveloped wings that inhabit the plant cover searching for their food (usually smaller insects or plant tissues). Tettigonia is one of the most notable Old World example with two centers of diversity: one in the Mediterranean-Pontic region (see, e.g., Ramme 1951; Pinedo 1985; Chobanov et al. 2014) and another in the Japanese archipelago (see Ichikawa et al. 2006; Kim et al. 2016). Both regions are characterized by a similar number of endemic taxa and insufficient knowledge regarding the taxonomy and systematics of Green Bushcrickets (Ichikawa et al. 2006; Chobanov et al. 2014; own unpublished data).

Despite the fact that several species of Green Bush-crickets are quite well known and have been the subject of detailed neuro-ethological studies (e.g., Zhantiev and Korsunovskaya 1978; Schul 1998), others remain poorly known from single specimens, and even nowadays, the discovery of new species continues (Ogawa 2003; Ichikawa et al. 2006; Chobanov et al. 2014; Storozhenko et al. 2015). Data on the systematics of this genus involve piecemeal morpho-acoustic studies conducted for geographically restricted areas or focused on 
morphological groups of species (e.g., Heller 1988; Rhee 2013; Chobanov et al. 2014). Our recent morphological and acoustic studies on Tettigonia, concentrated on the Western Palaearctic, revealed a number of conflicts within the published data when trying to identify certain populations and develop hypotheses about the systematics of the group (own unpublished data). The latter further supports the need to use new markers to test the systematic position of some taxa and unravel the evolutionary history of this genus.

The evolution of acoustic communication systems in orthopterans has led to high levels of acoustic specialization. As acoustic signals are important for intraspecific and sex recognition as well as for interspecific isolation (Paterson 1985; Hochkirch and Lemke 2011), they are of great significance for studying the processes underlying evolutionary radiation. Acoustic diversity within bushcricket genera varies from very low with a more or less uniform pattern of the male calling song (cf. Heller 2006; Çıplak et al. 2009) to very high with a great variety of song types, especially in sympatric taxa, even within groups of closely related species (cf. Heller 1988, 1990, 2006; Chobanov and Heller 2010, etc.).

In Tettigonia, song differences between species (especially well expressed in sympatric taxa) may express in different syllable arrangement and repetition rate, echeme length, and duty cycle. Some differences are also found in the carrier frequency of the song. In some species (e.g., Tettigonia cantans), females are not very sensitive to the conspecific structure of the song and thus may respond to heterospecific males (Schul et al. 1998), while in other species (i.e., Tettigonia caudata), females rely on the minimum duty cycle of the echemes, thus neglecting the fine song structure (Schul 1998). In Tettigonia viridissima, song recognition based on temporal clues has been shown to be more complicated. Here, females evaluate the pause within disyllabic echemes and respond only to the species-specific echeme structure (Schul 1998).

In the present study, we aim to evaluate phylogenetic relationships within Tettigonia. We based our study on a genetic dataset that was used as a basis for mapping acoustic and morphological characters in an attempt to track the evolutionary paths of the acoustic communication in this genus. For these purposes, sequences of the mitochondrial cytochrome c oxidase subunit I (COI) gene and the nuclear internal transcribed spacers 1 and 2 (ITS1 and ITS2) were used that have previously been widely employed in phylogenetic studies of grasshoppers (e.g., Cooper et al. 1995; Chapco and Litzenberger 2002) and bush-crickets (Ullrich et al. 2010; Allegrucci et al. 2011; Boztepe et al. 2013; Çiplak et al. 2015). The DNA sequences selected for the present study have different modes of evolution and inheritance history, and thus, they may reveal different aspects of the speciation history of the examined lineages.
In bush-crickets, the songs of closely related species, especially those that speciated in allopatry, usually have a lineage-specific amplitude-temporal pattern that enables recognition for systematic purposes and for drawing conclusions about paths of speciation (e.g., Heller 1990, 2006; Chobanov and Heller 2010). In Tettigonia, differences between species have been observed in the time and frequency domains, while particular song-recognizing mechanisms may depend on the geographic and ecological preferences of the species (Schul 1994; Schul et al. 1998). Hence, we use the male calling song as an additional clue for evolutionary assumptions as well as for testing the variation of song types according to genetic or morphological units. Thus, the present study indirectly vindicates the significance of acoustic recognition systems and song specialization patterns in this genus.

\section{Material and methods}

\section{Taxon sampling and morphological identification}

The species used in this study and their sampling localities are presented in Table 1 and Fig. 1. This dataset contains 66 Tettigonia specimens from 33 disjunct localities/ populations and five outgroup taxa representing two tettigoniid subfamilies (Tettigoniinae: Amphiestris Fieber, 1853 (Tettigoniini), Onconotus Fischer von Waldheim, 1839, Paratlanticus Ramme, 1939, Platycleis Fieber, 1853; Saginae: Saga pedo (Pallas, 1771)). Due to the properties of the chosen DNA fragments (high amount of interspecific variation providing good phylogenetic signal at a generic level but some risk of false results at a higher systematic level due to convergencies and phenomena like long branch attraction), we choose taxa that, according to published data, are closely related and/or have close ancestral position to Tettigonia (in the case of Saginae) (e.g., Gorochov 1995; Song et al. 2015).

Used samples of Tettigonia have preliminary been identified using original descriptions and published reviews (e.g., Bolívar 1914; Chopard 1943; Ramme 1951; Harz 1969; Massa 1998; Chobanov et al. 2014 and references therein). All specimens listed in Table 1 were morphologically related to existing taxa based on available literature and museum specimens. Apart from own material, the following specimens from public collections that refer to the studied taxa were studied:

Tettigonia acutipennis Ebner, 1946-male, holotype, "Kleinasien 1914 | Marasch, Tölg. | coll. R. Ebner" (Naturhistorisches Museum Wien (NHMW)); male, Hakkari (the Natural History Museum London (NHM)); two males, “Turkey: | Gumusane, | Soganli Gecidi, 7-7500'. | 25. vii. 
Table 1 Locality data for the specimens sequenced and specimens used for bioacoustics evaluation

\begin{tabular}{|c|c|c|c|c|c|c|}
\hline \multirow[t]{2}{*}{ Voucher ID } & \multirow[t]{2}{*}{ Species } & \multirow[t]{2}{*}{ Location } & \multirow{2}{*}{$\begin{array}{l}\text { Geographical } \\
\text { position }\end{array}$} & \multicolumn{3}{|c|}{ GenBank accession nos. } \\
\hline & & & & $\mathrm{COI}$ & ITS1 & ITS2 \\
\hline out1 & Saga pedo (Pallas, 1771) & $\begin{array}{l}\text { Bulgaria: E Stara Planina Mts, Zeravna } \\
\text { vill, } 900 \mathrm{~m}\end{array}$ & $\begin{array}{l}42.8427 \mathrm{~N} \\
26.4519 \mathrm{E}\end{array}$ & KT936310 & KT823256 & KT823233 \\
\hline out2 & Platycleis (Squamiana) sp. & Turkey: Zara-Susehri road, $1650 \mathrm{~m}$ & $\begin{array}{l}39.5556 \mathrm{~N} \\
37.9161 \mathrm{E}\end{array}$ & KT936311 & KT358278 & KT358337 \\
\hline out3 & $\begin{array}{l}\text { Onconotus servillei Fisher von } \\
\text { Waldheim, } 1846\end{array}$ & Bulgaria: Kapitan Dimitrovo vill. & $\begin{array}{l}43.95 \mathrm{~N} \\
27.7 \mathrm{E}\end{array}$ & KT936312 & KT358279 & KT358338 \\
\hline out4 & $\begin{array}{l}\text { Amphiestris baetica (Rambur, } \\
\text { 1838) }\end{array}$ & $\begin{array}{l}\text { Spain: Cultivo hija de otra de los Barrios, } \\
\text { Cadiz }\end{array}$ & $\begin{array}{l}36.32 \mathrm{~N} \\
6.17 \mathrm{~W}\end{array}$ & KT936313 & KT358280 & KT358339 \\
\hline out5 & $\begin{array}{l}\text { Paratlanticus ussuriensis } \\
\text { (Uvarov, 1926) }\end{array}$ & $\begin{array}{l}\text { Russia: Primorsky Krai, Lazovskii } \\
\text { Natural Reserve, Korpad }\end{array}$ & $\begin{array}{l}43.557 \mathrm{~N} \\
133.5726 \mathrm{E}\end{array}$ & KT936314 & KT358336 & КT358340 \\
\hline $\operatorname{tam} 1 \mathrm{a}$ & T. armeniaca complex & $\begin{array}{l}\text { Turkey: Horasan-Agri, Saclidag Pass, } \\
2160 \mathrm{~m}\end{array}$ & $\begin{array}{l}39.8747 \mathrm{~N} \\
42.3856 \mathrm{E}\end{array}$ & KT358223 & KT358281 & KT358341 \\
\hline $\operatorname{tam} 1 b$ & T. armeniaca complex & $\begin{array}{l}\text { Turkey: Horasan-Agri, Saclidag Pass, } \\
2160 \mathrm{~m}\end{array}$ & $\begin{array}{l}39.8747 \mathrm{~N} \\
42.3856 \mathrm{E}\end{array}$ & KT358224 & KT358282 & KT358342 \\
\hline $\operatorname{tam} 2 \mathrm{a}$ & T. armeniaca complex & $\begin{array}{l}\text { Turkey: Horasan-Agri, Savsat-Ardahan } \\
\text { road, } 1630 \mathrm{~m}\end{array}$ & $\begin{array}{l}41.2312 \mathrm{~N} \\
42.4338 \mathrm{E}\end{array}$ & KT358225 & KT358283 & KT358343 \\
\hline- & T. armeniaca complex & Turkey: Pulumur, $1818 \mathrm{~m}$ & $\begin{array}{l}39.51934 \mathrm{~N} \\
39.87208 \mathrm{E}\end{array}$ & - & - & - \\
\hline- & T. armeniaca complex & Turkey: Ispir, $1900 \mathrm{~m}$ & $\begin{array}{l}40.583 \mathrm{~N} \\
40.883 \mathrm{E}\end{array}$ & - & - & - \\
\hline- & T. armeniaca complex & Armenia: above Djermuk, $2400 \mathrm{~m}$ & $\begin{array}{l}39.86365 \mathrm{~N} \\
45.69338 \mathrm{E}\end{array}$ & - & - & - \\
\hline- & T. armeniaca complex & Armenia: E Saravan, 2290 m & $\begin{array}{l}39.68,531 \mathrm{~N} \\
45.70808 \mathrm{E}\end{array}$ & - & - & - \\
\hline- & T. armeniaca complex & $\begin{array}{l}\text { Armenia: Shorja near Sevan Lake, } \\
1965 \mathrm{~m}\end{array}$ & $\begin{array}{l}40.50,393 \mathrm{~N} \\
45.30347 \mathrm{E}\end{array}$ & - & - & - \\
\hline- & T. armeniaca complex & Armenia: Lermontovo vill., $1850 \mathrm{~m}$ & $\begin{array}{l}40.74874 \mathrm{~N} \\
44.66132 \mathrm{E}\end{array}$ & - & - & - \\
\hline- & T. armeniaca complex & Armenia: $\mathrm{N}$ of Vardaghbyur, $2015 \mathrm{~m}$ & $\begin{array}{l}40.99647 \mathrm{~N} \\
43.88796 \mathrm{E}\end{array}$ & - & - & - \\
\hline tca1 & T. cantans (Fuessly, 1775) & Hungary: Borzsony Mts & $\begin{array}{l}47.55 \mathrm{~N} \\
19.00 \mathrm{E}\end{array}$ & KT358226 & KT358284 & KT358344 \\
\hline tca $2 \mathrm{a}$ & T. cantans (Fuessly, 1775) & Poland: OPN, Dolina Sapowska & $\begin{array}{l}50.1236 \mathrm{~N} \\
19.4845 \mathrm{E}\end{array}$ & KT358227 & KT358285 & KT358345 \\
\hline tca2b & T. cantans (Fuessly, 1775) & Poland: OPN, Dolina Sapowska & $\begin{array}{l}50.1236 \mathrm{~N} \\
19.4845 \mathrm{E}\end{array}$ & KT358228 & KT358286 & KT358346 \\
\hline tca $2 c$ & T. cantans (Fuessly, 1775) & Poland: OPN, Dolina Sapowska & $\begin{array}{l}50.1236 \mathrm{~N} \\
19.4845 \mathrm{E}\end{array}$ & KT358229 & KT358287 & KT358347 \\
\hline tca2d & T. cantans (Fuessly, 1775) & Poland: OPN, Dolina Sąpowska & $\begin{array}{l}50.1236 \mathrm{~N} \\
19.4845 \mathrm{E}\end{array}$ & KT358230 & KT358288 & KT358348 \\
\hline tca2e & T. cantans (Fuessly, 1775) & Poland: OPN, Dolina Sappowska & $\begin{array}{l}50.1236 \mathrm{~N} \\
19.4845 \mathrm{E}\end{array}$ & KT358231 & KT358289 & KT358349 \\
\hline tca $2 f$ & T. cantans (Fuessly, 1775) & Poland: OPN, Dolina Sąpowska & $\begin{array}{l}50.1236 \mathrm{~N} \\
19.4845 \mathrm{E}\end{array}$ & KT358232 & KT358290 & KT358350 \\
\hline tca3a & T. cantans (Fuessly, 1775) & Romania: Lepsa & $\begin{array}{l}45.57 \mathrm{~N} \\
26.34 \mathrm{E}\end{array}$ & KT358244 & KT358291 & KT358351 \\
\hline tca3b & T. cantans (Fuessly, 1775) & Romania: Lepsa & $\begin{array}{l}45.57 \mathrm{~N} \\
26.34 \mathrm{E}\end{array}$ & KT358245 & KT358292 & KT358352 \\
\hline tca3c & T. cantans (Fuessly, 1775) & Romania: Lepsa & $\begin{array}{l}45.57 \mathrm{~N} \\
26.34 \mathrm{E}\end{array}$ & KT358247 & KT358293 & KT358353 \\
\hline tca3d & T. cantans (Fuessly, 1775) & Romania: Lepsa & $\begin{array}{l}45.57 \mathrm{~N} \\
26.34 \mathrm{E}\end{array}$ & KT358246 & KT358294 & KT358357 \\
\hline $\operatorname{tct} 3$ & T. cantans (Fuessly, 1775) & $\begin{array}{l}\text { China: Xinjiang, near Tianchi } \\
\text { (or Tienchi/Heaven Lake) in Tianshan } \\
\text { Mts. near mountain of Bogda Feng, } \\
2000 \mathrm{~m}\end{array}$ & $\begin{array}{l}43.9 \mathrm{~N} \\
88.117 \mathrm{E}\end{array}$ & KT358235 & KT358297 & KT358357 \\
\hline tct1 & T. cantans (Fuessly, 1775) & Kyrgyzstan: Isik Ata & $\begin{array}{l}42.53 \mathrm{~N} \\
74.51 \mathrm{E}\end{array}$ & KT358233 & KT358295 & KT358355 \\
\hline- & T. caudata (Charpentier, 1842) & Turkey: Ispir, $1900 \mathrm{~m}$ & $\begin{array}{l}40.583 \mathrm{~N} \\
40.883 \mathrm{E}\end{array}$ & - & - & - \\
\hline
\end{tabular}


Table 1 (continued)

\begin{tabular}{|c|c|c|c|c|c|c|}
\hline \multirow[t]{2}{*}{ Voucher ID } & \multirow[t]{2}{*}{ Species } & \multirow[t]{2}{*}{ Location } & \multirow{2}{*}{$\begin{array}{l}\text { Geographical } \\
\text { position }\end{array}$} & \multicolumn{3}{|c|}{ GenBank accession nos. } \\
\hline & & & & $\mathrm{COI}$ & ITS1 & ITS2 \\
\hline- & T. caudata (Charpentier, 1842) & $\begin{array}{l}\text { Armenia: Gorhajk near Vorotan Dam, } \\
2120 \mathrm{~m}\end{array}$ & $\begin{array}{l}39.68521 \mathrm{~N} \\
45.78486 \mathrm{E}\end{array}$ & - & - & - \\
\hline $\operatorname{tct} 2$ & T. caudata (Charpentier, 1842) & Bulgaria: Byala & $\begin{array}{l}43.4717 \mathrm{~N} \\
25.7696 \mathrm{E}\end{array}$ & KT358234 & KT358296 & KT358356 \\
\hline $\operatorname{tdm}$ & T. uvarovi Ebner, 1946 & $\begin{array}{l}\text { Russia: Primorsky Krai, Ussuri River, } \\
\text { Gornye Kluchi (Shamkovka) }\end{array}$ & $\begin{array}{l}45.20 \mathrm{~N} \\
134.40 \mathrm{E}\end{array}$ & KT358236 & KT358298 & KT358358 \\
\hline tmola & T. cf. longealata & Morocco: S Ajabo, $1360 \mathrm{~m}$ & $\begin{array}{l}33.0659 \mathrm{~N} \\
5.4086 \mathrm{~W}\end{array}$ & KT358254 & KT358299 & KT358359 \\
\hline tmolb & $T$. cf. longealata & Morocco: S Ajabo, 1360 m & $\begin{array}{l}33.0659 \mathrm{~N} \\
5.4086 \mathrm{~W}\end{array}$ & KT358252 & KT358300 & KT358360 \\
\hline tmolc & $T$. cf. longealata & Morocco: S Ajabo, $1360 \mathrm{~m}$ & $\begin{array}{l}33.0659 \mathrm{~N} \\
5.4086 \mathrm{~W}\end{array}$ & KT358253 & KT358301 & KT358361 \\
\hline $\operatorname{tmo} 2 \mathrm{a}$ & T. cf. longealata & Morocco: NW Khenifra, 1100 m & $\begin{array}{l}33.1377 \mathrm{~N} \\
5.9235 \mathrm{~W}\end{array}$ & KT358261 & KT358302 & KT358362 \\
\hline tmo2b & T. cf. longealata & Morocco: NW Khenifra, 1100 m & $\begin{array}{l}33.1377 \mathrm{~N} \\
5.9235 \mathrm{~W}\end{array}$ & KT358262 & KT358303 & KT358363 \\
\hline $\operatorname{tmo} 2 \mathrm{c}$ & T. cf. vaucheriana & Morocco: NW Khenifra, 1100 m & $\begin{array}{l}33.1377 \mathrm{~N} \\
5.9235 \mathrm{~W}\end{array}$ & KT358248 & KT358304 & KT358364 \\
\hline tmo3a & T. cf. vaucheriana & Morocco: near El Kebab, 966 m & $\begin{array}{l}32.7569 \mathrm{~N} \\
5.6451 \mathrm{~W}\end{array}$ & KT358257 & KT358305 & KT358365 \\
\hline tmo3b & T. cf. vaucheriana & Morocco: near El Kebab, 966 m & $\begin{array}{l}32.7569 \mathrm{~N} \\
5.6451 \mathrm{~W}\end{array}$ & KT358251 & KT358306 & KT358366 \\
\hline tmo3c & T. cf. vaucheriana & Morocco: near El Kebab, 966 m & $\begin{array}{l}32.7569 \mathrm{~N} \\
5.6451 \mathrm{~W}\end{array}$ & KT358249 & KT358307 & KT358367 \\
\hline tmo3d & T. cf. vaucheriana & Morocco: near El Kebab, 966 m & $\begin{array}{l}32.7569 \mathrm{~N} \\
5.6451 \mathrm{~W}\end{array}$ & KT358250 & KT358308 & KT358368 \\
\hline tmo3e & T. cf. vaucheriana & Morocco: near El Kebab, 966 m & $\begin{array}{l}32.7569 \mathrm{~N} \\
5.6451 \mathrm{~W}\end{array}$ & KT358242 & KT358309 & KT358369 \\
\hline tmo4a & T. cf. vaucheriana & Morocco: SE Thar Es-Souk, 650 m & $\begin{array}{l}34.6585 \mathrm{~N} \\
4.2417 \mathrm{~W}\end{array}$ & KT358258 & KT358310 & KT358370 \\
\hline tmo4b & T. cf. vaucheriana & Morocco: SE Thar Es-Souk, 650 m & $\begin{array}{l}34.6585 \mathrm{~N} \\
4.2417 \mathrm{~W}\end{array}$ & KT358260 & KT358311 & KT358371 \\
\hline tmo5a & T. cf. viridissima & Morocco: S Aïn Zora, 835 m & $\begin{array}{l}34.5708 \mathrm{~N} \\
3.6657 \mathrm{~W}\end{array}$ & KT358256 & KT358312 & KT358372 \\
\hline tmo5b & T. cf. viridissima & Morocco: S Aïn Zora, 835 m & $\begin{array}{l}34.5708 \mathrm{~N} \\
3.6657 \mathrm{~W}\end{array}$ & KT358263 & KT358313 & KT358373 \\
\hline $\operatorname{tmo} 5 \mathrm{c}$ & T. cf. viridissima & Morocco: S Aïn Zora, 835 m & $\begin{array}{l}34.5708 \mathrm{~N} \\
3.6657 \mathrm{~W}\end{array}$ & KT358255 & KT358314 & KT358374 \\
\hline tmo5d & T. cf. viridissima & Morocco: S Aïn Zora, 835 m & $\begin{array}{l}34.5708 \mathrm{~N} \\
3.6657 \mathrm{~W}\end{array}$ & KT358265 & KT358315 & KT358375 \\
\hline tmo5e & T. cf. viridissima & Morocco: S Aïn Zora, 835 m & $\begin{array}{l}34.5708 \mathrm{~N} \\
3.6657 \mathrm{~W}\end{array}$ & KT358264 & KT358316 & KT358376 \\
\hline tmo6a & T. cf. vaucheriana & Morocco: Bouchfaa W Taza, 675 m & $\begin{array}{l}34.0830 \mathrm{~N} \\
4.2996 \mathrm{~W}\end{array}$ & KT358239 & KT358317 & KT358377 \\
\hline tmo6b & T. cf. vaucheriana & Morocco: Bouchfaa W Taza, 675 m & $\begin{array}{l}34.0830 \mathrm{~N} \\
4.2996 \mathrm{~W}\end{array}$ & KT358238 & KT358318 & KT358378 \\
\hline tmo7a & T. sp. aff. viridissima & Morocco: E Azrou, 1520 m & $\begin{array}{l}33.4259 \mathrm{~N} \\
5.1926 \mathrm{~W}\end{array}$ & KT358268 & KT358319 & KT358379 \\
\hline tmo $7 b$ & T. sp. aff. viridissima & Morocco: E Azrou, 1520 m & $\begin{array}{l}33.4259 \mathrm{~N} \\
5.1926 \mathrm{~W}\end{array}$ & KT358266 & KT358320 & KT358380 \\
\hline $\operatorname{tmo} 7 \mathrm{c}$ & T. sp. aff. viridissima & Morocco: E Azrou, 1520 m & $\begin{array}{l}33.4259 \mathrm{~N} \\
5.1926 \mathrm{~W}\end{array}$ & KT358267 & KT358321 & KT358381 \\
\hline $\operatorname{tmo} 7 d$ & T. sp. aff. viridissima & Morocco: E Azrou, 1520 m & $\begin{array}{l}33.4259 \mathrm{~N} \\
5.1926 \mathrm{~W}\end{array}$ & KT358243 & KT358322 & KT358382 \\
\hline tmo8a & T. cf. vaucheriana & Morocco: Tilougguite Pass, $1570 \mathrm{~m}$ & $\begin{array}{l}32.0852 \mathrm{~N} \\
6.3003 \mathrm{~W}\end{array}$ & KT358241 & KT358323 & KT358383 \\
\hline tmo8b & T. cf. vaucheriana & Morocco: Tilougguite Pass, 1570 m & $\begin{array}{l}32.0852 \mathrm{~N} \\
6.3003 \mathrm{~W}\end{array}$ & KT358240 & KT358324 & KT358384 \\
\hline tmo9 & T. cf. vaucheriana & Morocco: SW Derdara, 400 m & $\begin{array}{l}35.0896 \mathrm{~N} \\
5.3074 \mathrm{~W}\end{array}$ & KT358259 & KT358325 & KT358385 \\
\hline
\end{tabular}


Table 1 (continued)

\begin{tabular}{|c|c|c|c|c|c|c|}
\hline \multirow[t]{2}{*}{ Voucher ID } & \multirow[t]{2}{*}{ Species } & \multirow[t]{2}{*}{ Location } & \multirow{2}{*}{$\begin{array}{l}\text { Geographical } \\
\text { position }\end{array}$} & \multicolumn{3}{|c|}{ GenBank accession nos. } \\
\hline & & & & $\mathrm{COI}$ & ITS1 & ITS2 \\
\hline- & T. cf. vaucheriana & Morocco: N Fes, $20 \mathrm{~m}$ & $\begin{array}{l}34.47138 \mathrm{~N} \\
5.38195 \mathrm{~W}\end{array}$ & - & - & - \\
\hline- & T. cf. vaucheriana & Morocco: Tilougguite Pass, $1570 \mathrm{~m}$ & $\begin{array}{l}32.08519 \mathrm{~N} \\
6.30028 \mathrm{~W}\end{array}$ & - & - & - \\
\hline tvi1 & T. viridissima (Linnaeus, 1758) & Kyrgyzstan: Ata Arche & $\begin{array}{l}42.3842 \mathrm{~N} \\
74.2848 \mathrm{E}\end{array}$ & KT358273 & KT358326 & KT358386 \\
\hline tvi2 & T. viridissima (Linnaeus, 1758) & Spain: Isik Ata, Montes de Toledo & $\begin{array}{l}39.3045 \mathrm{~N} \\
04.4353 \mathrm{~W}\end{array}$ & KT358237 & KT358327 & KT358387 \\
\hline tvi3a & T. viridissima (Linnaeus, 1758) & Ukraine: Donetsk Region & $\begin{array}{l}48.14 \mathrm{~N} \\
37.74 \mathrm{E}\end{array}$ & KT358274 & KT358328 & KT358388 \\
\hline tvi3b & T. viridissima (Linnaeus, 1758) & Ukraine: Donetsk Region & $\begin{array}{l}48.14 \mathrm{~N} \\
37.74 \mathrm{E}\end{array}$ & KT358275 & KT358329 & KT358389 \\
\hline tvi3c & T. viridissima (Linnaeus, 1758) & Ukraine: Donetsk Region & $\begin{array}{l}48.14 \mathrm{~N} \\
37.74 \mathrm{E}\end{array}$ & KT358276 & KT358330 & KT358390 \\
\hline tvi3d & T. viridissima (Linnaeus, 1758) & Ukraine: Donetsk Region & $\begin{array}{l}48.14 \mathrm{~N} \\
37.74 \mathrm{E}\end{array}$ & KT358277 & KT358331 & KT358391 \\
\hline tvi4 & T. viridissima (Linnaeus, 1758) & Turkey: Yanikcay, $1920 \mathrm{~m}$ & $\begin{array}{l}38.2547 \mathrm{~N} \\
42.8978 \mathrm{E}\end{array}$ & KT358269 & KT358332 & KT358392 \\
\hline tvi5a & T. viridissima (Linnaeus, 1758) & Bulgaria: Varna, Botanical Garden & $\begin{array}{l}43.2374 \mathrm{~N} \\
28.003 \mathrm{E}\end{array}$ & KT358272 & KT358333 & KT358393 \\
\hline tvi5b & T. viridissima (Linnaeus, 1758) & Bulgaria: Haskovo, Perperikon Ruins & $\begin{array}{l}41.715 \mathrm{~N} \\
25.4657 \mathrm{E}\end{array}$ & KT358270 & KT358334 & KT358394 \\
\hline tvi5c & T. viridissima (Linnaeus, 1758) & Bulgaria: Dobrich, Bolata Bay & $\begin{array}{l}43.3838 \mathrm{~N} \\
28.4715 \mathrm{E}\end{array}$ & KT358271 & KT358335 & KT358395 \\
\hline
\end{tabular}

All sequences are submitted to the NCBI GenBank

1960. | K. M. Guichard | \& D. H. Harvey. | B.M. 1960-364" (NHM).

Tettigonia armeniaca stat. nov.- two females (not identified), "Isbisu (Gov. Eriwan)" (NHMW); female (not identified), "Bakurian" [Georgia] (NHMW); male (not identified), "Kasikoparan" [Turkey] (NHMW); male (not identified), "Soganli Gecidi" [Turkey] (NHMW)

T. cantans (Fuessly, 1775)—male, "Karnten 1927 | Vellacher Toschna, 3. ix. | coll. R. Ebner" (NHMW)

T. caudata (Charpentier, 1842)-male, "Jasenova, Jugoslawien" (NHMW); male, "Pirot" (NHMW); male, "Walouiki, R. m. | Velitchkovsky" [Ukraine] (NHMW); male, "Gegend v. Wien | Von Hn. Turk | Coll. Br. v. W." (NHMW); male, "Eriwan-Tiflis" (NHMW); male, "Poin-Shaval, Elbrus Funke leg." (NHMW); male, "Persia s.- | Elburs | RehneDemavend | ca. 2700-3600 m | 20-27. vii. 1936" (NHMW); male, "Sabzawaran | 12. v. 50 / Ö sterr. | Iran exped. 1950" (NHMW); male, "Afghanistan $\mid$ Chira $\mid$ Hr. v. Pleson $\mid$ Coll. Br. v. W." (NHMW)

Tettigonia lozanoi (Bolívar, 1914)—male, Aguelman (NHM)

Tettigonia uvarovi Ebner, 1946-male, holotype, Siberia (NHMW)

Tettigonia vaucheriana Pictet, 1888-male, "Morocco, Azrou, 1200-1400 m, 28. v.-1. vi. 1930. Ebner" (NHMW); female, "Atlas, Asni | 1200 m, 23-30. vi.' 30. | Ebner" (NHMW)

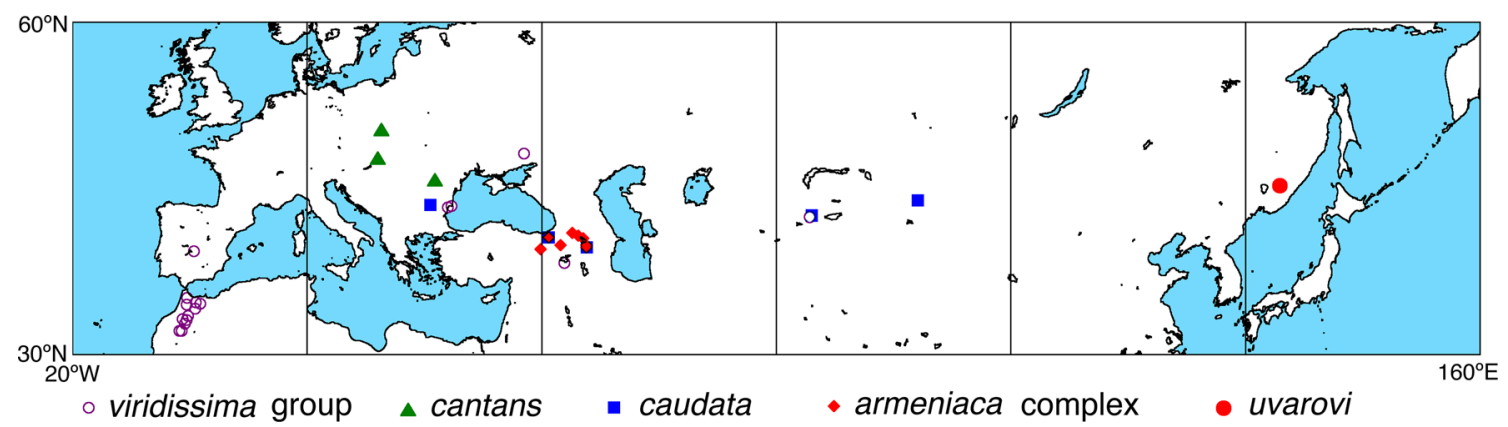

Fig. 1 Map showing the sampling sites for Tettigonia 
According to the state of knowledge, taxonomic recognition and morphological similarities, we divided Tettigonia taxa into three groups:

1. Commonly recognized taxa: well-studied T. viridissima (Linnaeus, 1758), T. caudata (Charpentier, 1842) s. str., and T. cantans (Fuessly, 1775) of the Western Palaearctic.

2. Taxa that have been recently described and only partially studied: Tettigonia dolichoptera maritima Storozhenko, $1994=$ T. uvarovi Ebner, 1946 (see Storozhenko et al. 2015). Described from the Russian Far East, this subspecies was thought to differ in the length of the pronotum and tegmina from the nominotypical form from South Korea. However, many South Korean specimens are similar to T. uvarovi in their dimensions (Rhee 2013), and only the most long-winged ones are now assumed to represent $T$. dolichoptera (Storozhenko et al. 2015). In any case, this representative of the Eastern Palaearctic fauna may provide clues as to the relationships and phylogeographic connections of the east and west Palaearctic lineages of Tettigonia.

3. Poorly known sibling species termed here as follows:

(a) The T. armeniaca complex. Upon sampling of a specific shorter-winged Tettigonia, resembling T. caudata in terms of many morphological features, which occurs from Eastern Anatolia to Southern Caucasus and possibly further to Kyrgyzstan (own unpublished information), we failed to definitely outline morpho-units that fit each of the taxa T. caudata armeniaca Tarbinsky, 1940 (presently a synonym of $T$. caudata s. str.), T. acutipennis Ebner, 1946, and Tettigonia turcica Ramme, 1951. This complex has been previously defined by weak (but present) black coloration at the base of ventral post-femoral spines and more or less shortened wings.

(b) The T. vaucheriana complex. A multitude of forms has been described from northwestern Africa, differing mostly in size, length of the forewings, and relative width of the scapus (front border of the vertex bordering the frons) ( $T$. vaucheriana Pictet, 1888 = Tettigonia maroccana Bolívar, 1893, syn.; T. lozanoi (Bolívar, 1914); Tettigonia longealata Chopard, 1937; Tettigonia krugeri Massa, 1998). Some of them resemble $T$. viridissima, which has been recorded from North Africa. Upon extensive sampling in Morocco and comparison of museum specimens, we observed a significant overlap between populations, with extreme examples ranging from a slender body shape with long wings (T. viridissima type) to a stout body with long wings (T. longealata) or short wings (T. vaucheriana,
T. lozanoi) as this has already been noted by Pinedo (1985).

\section{Genomic sampling}

DNA extraction was performed using NucleoSpin ${ }^{\circledR}$ Tissue Kits (Macherey-Nagel, Düren, Germany) according to the standard protocol. DNA was used as a PCR template to amplify four genetic markers, including mitochondrial and nuclear genes. These were (1) partial cytochrome c oxidase subunit I (COI), (2) partial sequences of the first internal transcribed spacer (ITS1) of the nuclear ribosomal gene cluster, and (3) partial sequences of the second internal transcribed spacer (ITS2) of the nuclear ribosomal gene cluster. The COI gene was amplified with the primers LCO [5' GGT CAA CAA ATC ATA AAG ATA TTG G $\left.3^{\prime}\right]$ and HCO [5' TAA ACT TCA GGG TGA CCA AAA AAT CA 3'] (Folmer et al. 1994). For nuclear DNA, ITS1 regions were PCR amplified using the primers $18 \mathrm{~S}-28 \mathrm{~S}$ [5' TAG AGG AAG TAA AAG TCG 3'] (Weekers et al. 2001) and ITS-R1 [5' CAT TGA CCC ACG AGC C 3'] (Ullrich et al. 2010), whereas ITS2 regions were amplified using the primers ITS2-28S [5' GGA TCG ATG AAG AAC G 3'] and 28S-18S [5' GCT TAA ATT CAG CGG 3'] (Weekers et al. 2001).

PCR was performed in $30-\mu \mathrm{L}$ reaction volumes, which comprised 10 pmol of each primer, $10 \mathrm{mM}$ of each dNTP, $25 \mathrm{mM} \mathrm{MgCl}_{2}, 2.5 \mu \mathrm{L}$ 10× PCR buffer, $1 \mathrm{U}$ Taq polymerase (EURx, Gdańsk, Poland), and sterile $\mathrm{H}_{2} \mathrm{O}$.

To amplify COI, we used the following PCR protocol: 35 cycles at $95{ }^{\circ} \mathrm{C}$ for $50 \mathrm{~s}, 50^{\circ} \mathrm{C}$ for $1 \mathrm{~min}$ and $72{ }^{\circ} \mathrm{C}$ for $1 \mathrm{~min}$, with the final extension at $72{ }^{\circ} \mathrm{C}$ for $6 \mathrm{~min}$. PCR amplification of ITS1 and ITS2 consisted of 25 cycles at $95{ }^{\circ} \mathrm{C}$ for $1 \mathrm{~min}, 52^{\circ} \mathrm{C}$ for $1 \mathrm{~min} 50 \mathrm{~s}$, and $72^{\circ} \mathrm{C}$ for $2 \mathrm{~min}$, with the final extension at $72{ }^{\circ} \mathrm{C}$ for $10 \mathrm{~min}$. PCR products were purified with the Gene MATRIX PCR/DNA Clean-Up Purification Kit (EURx, Poland, following the standard protocol) and sequenced directly. Purified DNA was sequenced in both directions using the same primers as for PCR and the Big Dye Terminator 3.1 Cycle Sequencing Kit (Applied Biosystems), according to the manufacturer's instructions.

\section{Phylogenetic analyses}

DNA sequences were edited and compiled using Muscle (Edgar 2004). To test for pseudogenes, coding sequences (COI) were translated into protein with MEGA 6 (Tamura et al. 2013) using the standard invertebrate mitochondrial genetic code. No stop codons were observed. Nucleotide composition homogeneity within genes was tested with PAUP* 4.0b10 (Swofford 2002). Mean net genetic distances among clades were calculated using MEGA 6 (Tamura et al. 2013) 
within the Kimura two-parameter model (K2P, standard errors (SE) were obtained by bootstrapping with 1000 replicates).

Two different phylogenetic methods, maximum likelihood (ML) and Bayesian inference (BI), were used to infer evolutionary relationships. Following independent analysis for each COI, ITS1, and ITS2 dataset, the COI and ITS1 + ITS2 datasets were concatenated and further analyses were performed using the combined matrix. Evolutionary models for each dataset and combined dataset were selected using MrModeltest 2.3 (Nylander 2004) with the Akaike information criterion (Akaike 1974). Support for nodes in ML analysis was assessed with non-parametric bootstrapping (BP) using Phyml (Guindon and Gascuel 2003) with 1000 pseduoreplicates and ten random BioNJ trees, and parameters were estimated from each dataset within the model selected for the original dataset. BI of phylogenetic relationships using Metropolis-coupled Monte Carlo Markov chain (mcmc) simulation was performed with MrBayes 3.1 (Huelsenbeck and Ronquist 2001; Huelsenbeck et al. 2001). Posterior probabilities were based on two independent MCM runs, each composed of four chains (three heated chains and one cold chain). The mcmc simulations were run for 10,000,000 generations with sampling every 100 generations. The convergence of analyses was validated by monitoring likelihood values graphically using Tracer (Rambaut and Drummond 2007), and trees prior to stationarity were discarded as burn-in. A $50 \%$ majority-rule consensus tree was constructed from the remaining trees to estimate posterior probabilities (PPs). Phylogenetic trees were produced using TreeView (Page 1996) and FigTree software (Rambaut 2008).

\section{Bioacoustic evaluations}

Male songs were recorded under different environmental conditions using the following equipment: (1) Knowles BT-1759000 electret condenser microphone with a sensitivity of $-60 \pm 3 \mathrm{~dB}$ re $1 \mathrm{~V} / \mu$ bar at $1 \mathrm{kHz}$ and with a frequency response roll-off of about $10 \mathrm{kHz}$ and cutoff at over $45 \mathrm{kHz}$ (data combined from Irie 1995 and W. Schulze, FriedrichAlexander-Universität Erlangen-Nürnberg, personal communication), equipped with a custom-made preamplifier connected to a PC through an external soundcard (Transit USB, "MAudio") (48/96-kHz sampling rate), used in the lab; (2) Pettersson D500 external microphone with a frequency range corresponding to that of the Pettersson D500x recorder, being between $1(-6 \mathrm{~dB})-2 \mathrm{kHz}(-3 \mathrm{~dB})$ and $190 \mathrm{kHz}(500-\mathrm{kHz}$ sampling rate) (Lars Pettersson, personal communication), connected to a ZOOM H2 or ZOOM H4 handy recorder (Zoom Corporation) (96-kHz sampling rate), used in captivity and in nature; (3) UHER M645 microphone with a frequency response flat up to $20 \mathrm{kHz}$ connected to a UHER $4200 \mathrm{IC}$ tape recorder; and (4) Brüel and Kjaer 4135 microphone connected to a RACAL store 4DS tape recorder.
The bioacoustic terminology used in this study is as follows (based on Ragge and Reynolds 1998, modified from Chobanov et al. 2014): calling song - the song produced by an isolated male; echeme - a first-order grouping of syllables; echeme duration - the time measured from the beginning of the first to the end of the last syllable; echeme period - the span including an echeme and the following interval; syllable- the sound produced by one opening-and-closing movement of the tegmina; syllable period - the span including a syllable and the following interval, usually measured between syllable peaks; syllable repetition rate-reciprocal of the syllable period (unit $\mathrm{Hz}=1 / \mathrm{s}$ ); diplosyllables = disyllabic echemes-two syllables separated from the neighboring diplosyllables by longer silent intervals than those within each diplosyllable; duty cycle — during singing activity, the proportion of time spent actually singing: echeme duration divided by the echeme period (in $T$. viridissima duration of echeme sequences divided by duration of acoustic activity); and chirp - an isolated acoustic event regardless of its structure. Temperature during the recordings varied, but for evaluation, we used only temperature-independent structures (duty cycle) and relationships (relationship between temperaturedependent chirp duration and temperature-dependent interval duration). Differences between a daytime song consisting of chirps and a continuous nighttime song as in T. cantans were not observed in $T$. armeniaca complex nor in any other Tettigonia species.

We concentrate to the poorly studied groups of the here named $T$. armeniaca complex and $T$. vaucheriana complex. Altogether, nine continuous recordings under different conditions (temperature, time of the day, different male individual) from six remote localities of males, representing different morphotypes of the $T$. vaucheriana complex, were studied (see Fig. 2). From the T. armeniaca complex, we studied, respectively, 34 recordings from ten localities (partly represented in Fig. 3). Own data for the rest of the studied taxa were supplemented with published recordings and song measurements. Recordings of T. cantans and T. caudata caudata from Massa et al. (2012) are used for comparative purposes in the figures (see "Results" section).

The recordings used for duty cycle measurements included those made by the present authors as well as recordings from several published sound sources (Grein 1984; Bonnet 1995; Kleukers et al. 1997; Ragge and Reynolds 1998; Nielsen 2000; Odé and Fontana 2002; Bellmann 2004; Barataud 2007; Roesti and Keist 2009; Massa et al. 2012; Kocarek et al. 2013; Gomboc and Segula 2014) and from the Internet (SYSTAX 2015; data provided by G. Schmidt).

Processing of sound files, measurements, and preparation of oscillograms were performed with Audacity 2.0.3 (Audacity team 1999-2013), BatSound 4.1.4 (Pettersson Electronics and Acoustics AB 1996-2010), and Amadeus II (Martin Hairer; http://www.hairersoft.com). 
Fig. 2 Oscillograms of the song of the Tettigonia viridissima group (1-9) and T. cantans (10) recorded at two speeds: $1 \mathrm{~T}$. cf. longealata (MO: Ajabo, $T=20^{\circ} \mathrm{C}$ ), 2 T. cf. vaucheriana (MO: N Fes, $T=20^{\circ} \mathrm{C}$ ), 3 T. cf. vaucheriana (MO: Bouchfaa $\mathrm{W}$ of Taza, $\left.T=21^{\circ} \mathrm{C}\right), 4 T$. cf. vaucheriana (MO: Tilougguite Pass, $T=23{ }^{\circ} \mathrm{C}$ ), $5 \mathrm{~T}$. cf. vaucheriana and cf. longealata (MO: El Kebab, $T=25^{\circ} \mathrm{C}$ ), $6 T$. cf. vaucheriana (MO: El Kebab, $\left.T=28-30{ }^{\circ} \mathrm{C}\right), 7 \mathrm{~T}$. cf. viridissima (MO: S Aïn Zora, $T=22^{\circ} \mathrm{C}$ ), $8 T$. cf. viridissima (MO: S Aïn Zora, $\left.T=25^{\circ} \mathrm{C}\right), 9$ T. viridissima $(\mathrm{BG}$ : Sofia, $T=27^{\circ} \mathrm{C}$ ), and $10 \mathrm{~T}$. cantans (IT: Val Malene; from Massa et al. 2012, $T=15^{\circ} \mathrm{C}$ )). Scale bar for $A$ is $10 \mathrm{~s}$ and for $B$ $2 \mathrm{~s}$

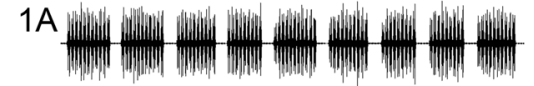

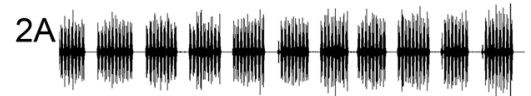
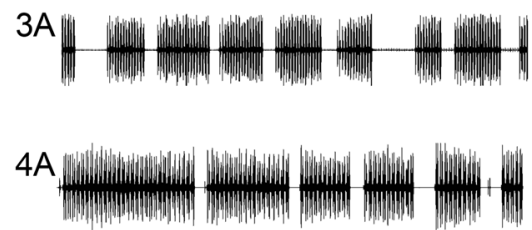

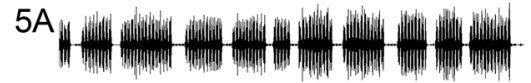

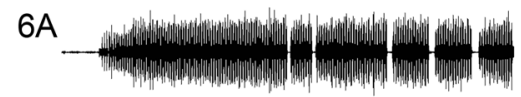

五

$8 \mathrm{~A}$

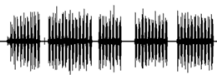

\section{$9 \mathrm{~A}$}

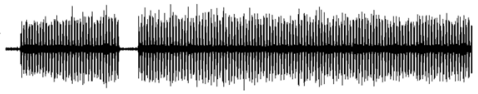

$10 \mathrm{~A}$

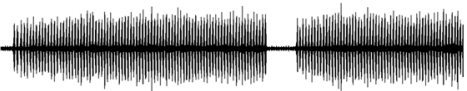

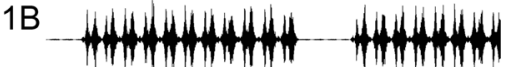
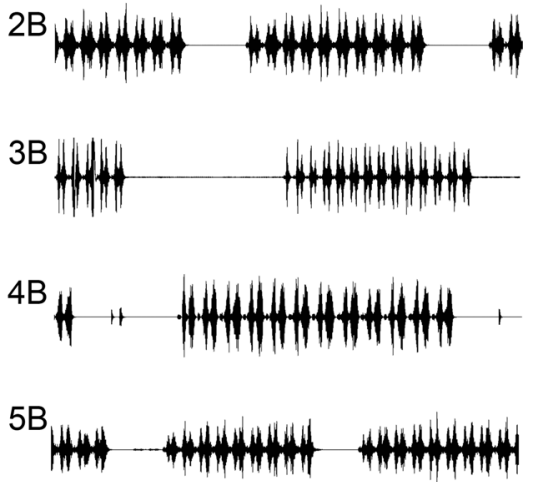

$6 \mathrm{~B}$

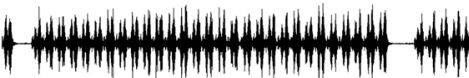

7B

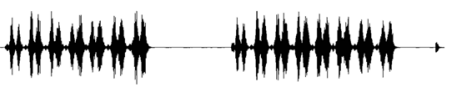

8B HAH HAHAHAHAHA HAHAHAHA

\section{$9 \mathrm{Ba}$}

HAHA HAHAHAHHAHAH

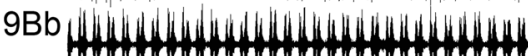
Hethm

$10 \mathrm{~B}$ HAHAHAHAHAHWHAHHWHA

\section{Results}

\section{Phylogenetic reconstruction}

COI, ITS1, and ITS2 genes are standard markers used in phylogenetic studies of insects, which in many cases have proved informative on a specific and generic level. We obtained the following fragments: $547 \mathrm{bp}$ for COI, $400 \mathrm{bp}$ for ITS1, and $420 \mathrm{bp}$ for ITS2 (including gaps and variable regions). No indels were observed in the COI fragment.

The congruency of COI, ITS1, and ITS2 $(p=0.99)$ allowed for these markers to be combined into a single matrix. The resulting $1367 \mathrm{bp}$ matrix was obtained after alignment and trimming, containing $20 \%$ variable and $13 \%$ parsimony informative sites. MrModeltest identified the GTR + G model (gamma distribution shape parameter $G=0.94 ;-\operatorname{lnL}=12,691.23$;
$\mathrm{AIC}=25,400.47)$ as the best nucleotide substitution model for ML and BI analyses.

Phylogenies reconstructed based on the combined data using ML and Bayesian methods (Fig. 4) showed similar topologies. The tree inferred from COI + ITS1 + ITS2 sequences (Fig. 4) showed that Tettigonia taxa are grouped into three main clades. Clade "A" includes all sampled populations of T. viridissima and all northwestern African specimens of the taxon referred to in this paper as the T. vaucheriana complex. Clade " $\mathrm{B}$ " is composed of T. caudata, T. uvarovi, and what is here referred to as the $T$. armeniaca complex. Clade " $\mathrm{C}$ " is composed of all the $T$. cantans samples in our dataset.

The genetic distances between and within clades for all genes are presented in Tables 2 and 3, respectively. Genetic distances between major clades were similar for COI (1-4\%) and for ITS (1-3\%). The genetic distances between ingroup species were very low for COI $(0-2 \%)$. 
Fig. 3 Oscillograms of songs of the Tettigonia armeniaca complex (1-11), T. caudata (12), and $T$. uvarovi (13) recorded at two or three speeds: $1 \mathrm{~T}$. armeniaca (AM: Djermuk, $\left.T=19^{\circ} \mathrm{C}\right), 2$ T. armeniaca (TR: Saclidag Pass, $\left.T=21.5^{\circ} \mathrm{C}\right), 3 T$. armeniaca (TR: Ispir, $T=17^{\circ} \mathrm{C}$ ) (monosyllabic type), $4 \mathrm{~T}$.

armeniaca (TR: Ispir, $T=17^{\circ} \mathrm{C}$ ) (disyllabic type), $5 \mathrm{~T}$. armeniaca (AM: Saravan, $T=20-25^{\circ} \mathrm{C}$ ) (outdoor recording), $6 T$. armeniaca (AM: Lermontovo vill., $T=20^{\circ} \mathrm{C}$ ), $7 \mathrm{~T}$. armeniaca (TR: Savsat-Ardahan, $T=26^{\circ} \mathrm{C}$ ), 8 T. armeniaca (TR: SavsatArdahan, $T=26^{\circ} \mathrm{C}$ ) (variable echeme length), $9 \mathrm{~T}$. armeniaca (TR: Ispir, $T=17^{\circ} \mathrm{C}$ ) (polysyllabic type of variable length), 10 T. armeniaca (TR: Pulumur, $T=20-22{ }^{\circ} \mathrm{C}$ ) (shorter echemes), 11 T. armeniaca (TR: Pulumur, $T=20-22^{\circ} \mathrm{C}$ ) (the same specimen as in 10 longer echemes), 12 T. caudata (GR: Drama; from Massa et al. 2012, $T=25^{\circ} \mathrm{C}$ ), and 13 T. uvarovi (South Korea; from Kim 2009 as T. dolichoptera; see Rhee 2013). Scale bar for $A$ is $10 \mathrm{~s}$; for $B, 2 \mathrm{~s}$; and for $\mathrm{C}, 200 \mathrm{~ms}$
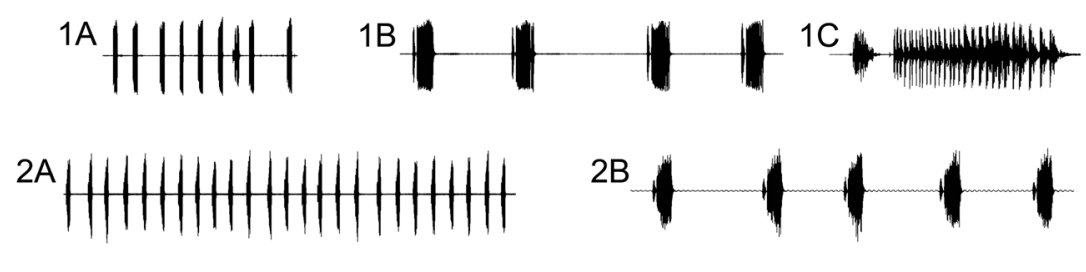

2B
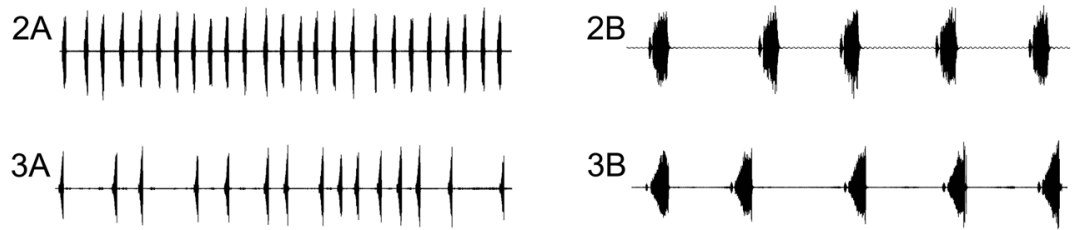

3B

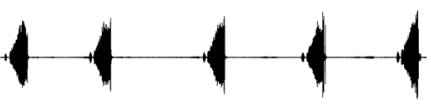

4A HHHHHHHHHHHHWHH

$4 \mathrm{~B}$
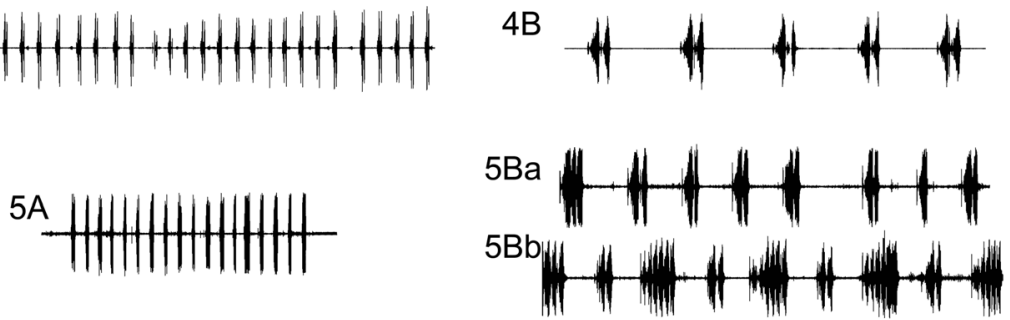

$6 \mathrm{~A}$

|IIIIIIIIIIII

$6 B$

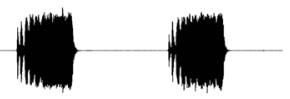

7A
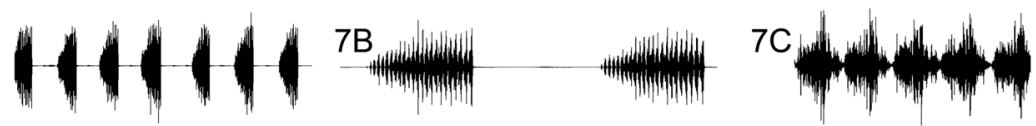

8A
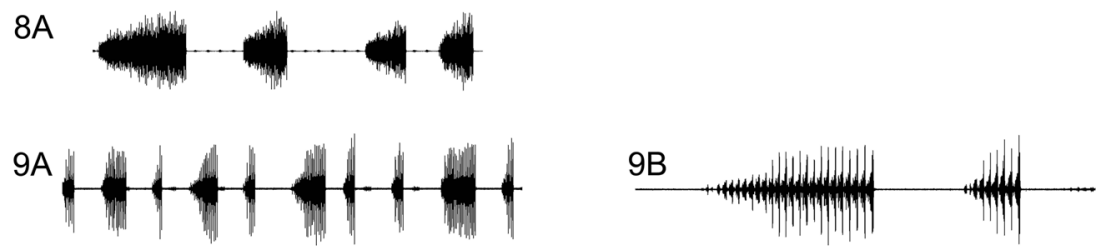

$10 \mathrm{~A}$

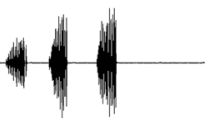

$10 \mathrm{~B}$

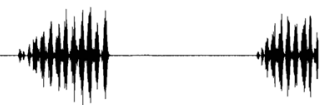

$11 \mathrm{~A}$

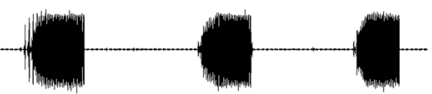

$12 \mathrm{~B}$

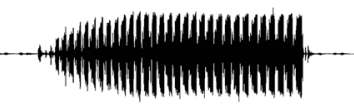

$12 \mathrm{~A}$

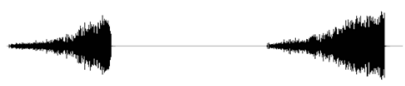

12B

$13 \mathrm{~A}$

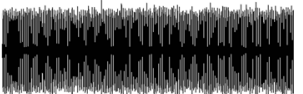

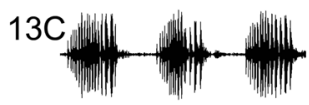

Scale for A - 10 s, B - 2 s, C - 200ms

\section{Bioacoustic evaluation and morphological characters}

The three bioacoustically well-distinguished species (see "Introduction" section) belong to three well-outlined clusters in our study. In addition to the previously known acoustic diversity in Central Europe, we found striking examples of variation among populations with uniform morphology, as well as uniform song patterns among morphologically distinct populations hitherto classified as different species.

Clade A (Figs. 4 and 5j-m) comprises haplotypes with low (COI) to very low (ITS) ingroup genetic distances. This clade includes populations from a large portion of the range of 


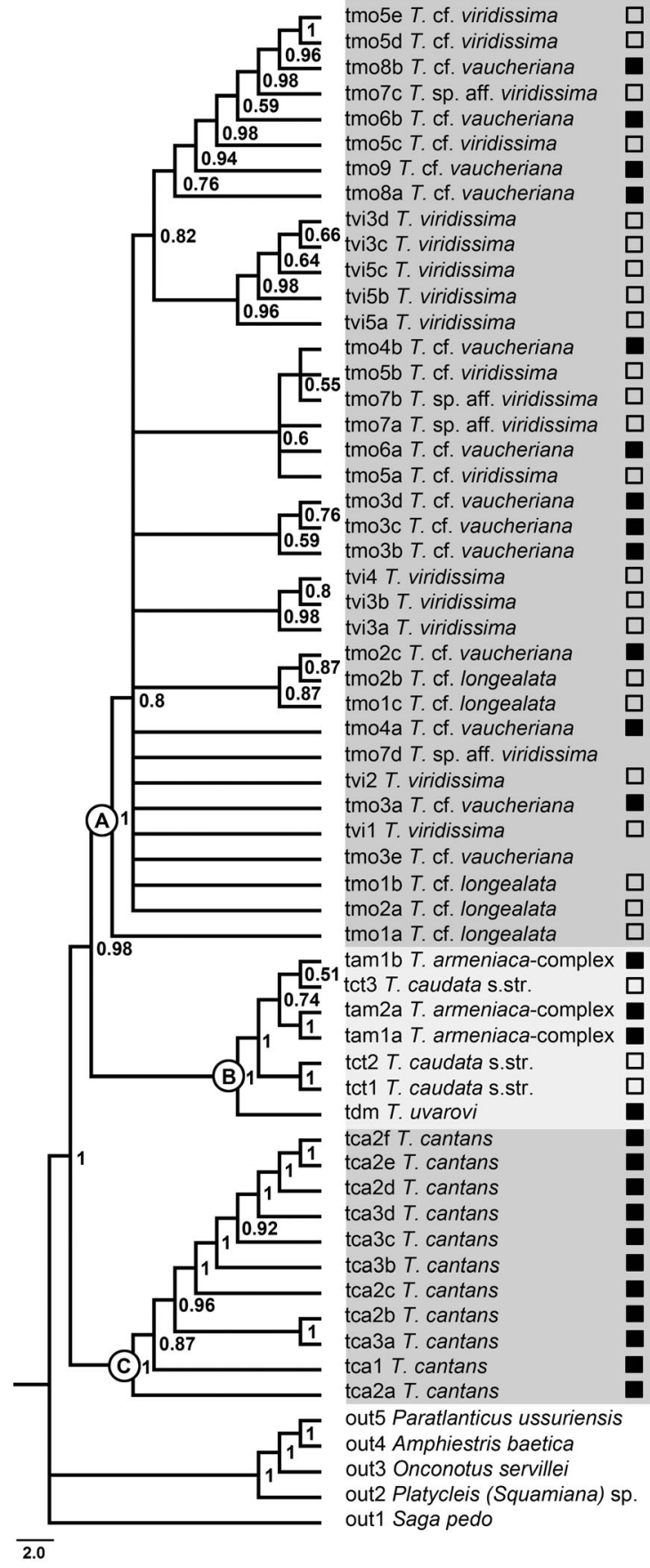

Fig. 4 Phylogenetic tree of the genus Tettigonia based on BI analysis of concatenated COI-ITS1-ITS2 sequences. BI posterior probability (PP) values are shown near resolved branches (only support values above 0.50). Species groups, as defined by genetic and morpho-acoustic data, are distinctly shaded, and the respective branches are marked with an open circle and a capital letter as follows: " $A$ " $-T$. viridissima group, " $B$ " - T. caudata group, and " $C$ " $-T$. cantans group. Haplotype codes correspond to Table 1 in the Supplement, followed by morphological identification. Squares on the right side of names correspond to relative wing length: filled squares short wings and open squares long wings;

T. viridissima as well as all populations sampled in Northwestern Africa that may be identified as one of
MO1

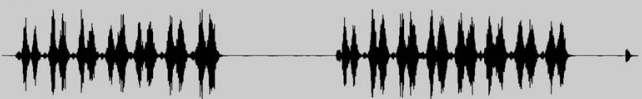

VI

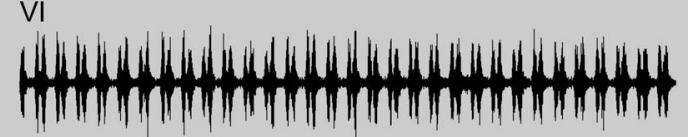

$\mathrm{MO} 2$

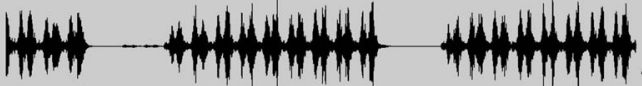

0

$\square 0$

$\square 0$
$\square 0$

A1

CT

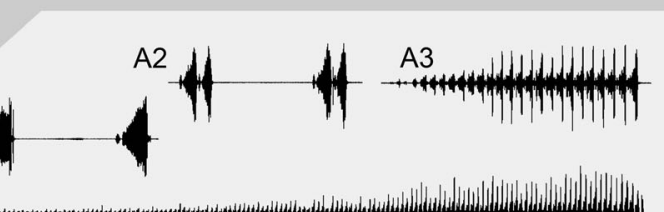

uv HIIIIIIIIIIIIIIIIIIIIIIIIIIIIIIIIIIII

CA

HHWHWHWHWHWHWH

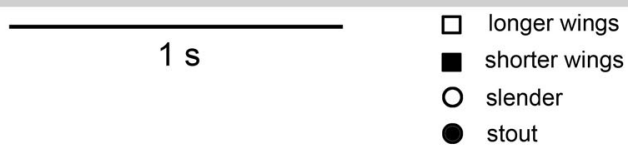

circles for the T. viridissima group correspond to relative body shape: filled circles larger and stouter body and open circles smaller and more slender body. A partial oscillogram with the main song types is presented for each group: $M O$ Moroccan populations of the T. viridissima group; $V I$ T. viridissima (specimen from Bulgaria); $A 1, A 2$, and $A 3$ three song types of different specimens of the T. armeniaca complex from the Erzurum region (Ispir); CT T. caudata (Greece, Drama; from Massa et al. 2012); DM T. uvarovi (S Korea; from Kim et al. 2009); CA T. cantans (Italy, Val Malene; from Massa et al. 2012). Scale bar corresponds to $1 \mathrm{~s}$ of recording (for temperature during recordings, see Figs. 2 and 3)

T. vaucheriana, T. lozanoi, T. longealata, T. krugeri, and T. viridissima. All these taxa were described in terms of 
Table 2 Net mean genetic distances (\%) between Tettigonia clades for mitochondrial (COI) and nuclear (ITS1 + ITS2) genes

\begin{tabular}{|c|c|c|c|c|c|}
\hline & & $\mathrm{T} 1$ & $\mathrm{~T} 2$ & $\mathrm{~T} 3$ & $\mathrm{~T} 4$ \\
\hline \multicolumn{6}{|l|}{ COI clades } \\
\hline T. viridissima + T vaucheriana complex & $\mathrm{T} 1$ & & & & \\
\hline T. uvarovi & $\mathrm{T} 2$ & 0.02 & & & \\
\hline $\begin{array}{l}\text { T. armeniaca complex }+T \text {. caudata } \mathrm{s} \text {. } \\
\text { str. }\end{array}$ & $\mathrm{T} 3$ & 0.03 & 0.02 & & \\
\hline T. caudata s. str. & $\mathrm{T} 4$ & 0.04 & 0.03 & 0.02 & \\
\hline T. cantans & $\mathrm{T} 5$ & 0.01 & 0.03 & 0.03 & 0.04 \\
\hline \multicolumn{6}{|l|}{ ITS1 + ITS2 clades } \\
\hline T. viridissima $+T$ vaucheriana complex & $\mathrm{T} 1$ & - & - & & \\
\hline T. uvarovi & $\mathrm{T} 2$ & 0.01 & - & & \\
\hline $\begin{array}{l}\text { T. armeniaca complex }+T \text {. caudata } \mathrm{s} \text {. } \\
\text { str. }\end{array}$ & $\mathrm{T} 3$ & 0.01 & 0.02 & & \\
\hline T. caudata s. str. & $\mathrm{T} 4$ & 0.02 & 0.02 & 0.01 & \\
\hline T. cantans & T5 & 0.02 & 0.03 & 0.01 & 0.01 \\
\hline
\end{tabular}

differences in body size, relative length of the tegmina (see open and closed symbols designating each specimen in Fig. 4), and some additional features, such as the width of the fastigium of the vertex (according to our observations in this group, a wide fastigium corresponds to large, stout body and vice versa). Despite these "strict" differences, we failed to clearly outline taxa as wide variation was observed between populations, and animals with both long and short wings occurred together in some areas. All sampled populations and studied museum specimens were compared (also with descriptions), and we did not find differences in the shape of male cerci and genitalia (titillators), female subgenital plate, or other species-specific characters.

All studied individuals from the sampled populations of clade A showed the same song pattern-sequences of disyllabic echemes of variable length separated by short intervals (see Fig. 2). Large intraindividual variation in the echeme sequence length was also observed. The fine structure of the song fully corresponded to that of $T$. viridissima though the latter species usually produced longer echeme sequences. Yet, a large overlap was detected between the song duty cycles (calculated using echemes and echeme intervals) of the northwestern African populations and T. viridissima (Fig. 6). The genetic data, showing low genetic diversification, support the phenotypic similarities.
Clade B (Fig. 4) is formed by T. uvarovi (Fig. 5c, d), T. caudata (Fig. 5e), and the T. armeniaca complex (Fig. 5fi). T. uvarovi is a well-characterized species, morphologically resembling $T$. viridissima, with a song more similar to that of T. cantans (Rhee 2013). T. caudata is also a well-studied species, though this only applies to its nominotypical form, while its relationships with subspecific taxa are vague. Its typical song, consisting of long echemes (1-10 s), was recorded from Switzerland in the west (Roesti and Keist 2009), through Europe and Anatolia, to China (Xinjiang) in the east (Fan et al. 2013). The T. armeniaca complex as here regarded concerns populations sampled in the Transcaucasus and Eastern Anatolia (see Table 1) with specimens fitting either T. caudata armeniaca, T. acutipennis, or T. turcica. All of the latter individuals were characterized in comparison with $T$. caudata $\mathrm{s}$. str. by more or less shortened wings, as well as shorter hind femora, smaller body size, and weaker development of black dots at the base of the ventral spines of the hind femora. Interestingly, although we could not discriminate between populations morphologically, specimens from different localities exhibited a wide variety of song types. The latter caused confusion not only for the fact that specimens with different songs looked the same, but due to the lack of a geographic structuring of the songs. Song types varied from long sequences of isolated syllables to sequences of disyllabic or polysyllabic echemes. However, all songs exhibited approximately the same relationship between chirp duration and chirp interval. Compared with the songs of T. caudata, the latter has higher absolute values in both aspects, still preserving the ratio between chirp duration and interval (Fig. 7). Part of the variation is certainly due to different temperatures during recording, but the groups did not overlap despite similar temperature ranges (T. armeniaca: $13-27.5^{\circ} \mathrm{C}$; T. caudata: $14-27^{\circ} \mathrm{C}$ ). The duty cycle of the armeniaca song (Fig. 6) varied significantly and partly overlapped with that of $T$. caudata.

After observation of dense populations of the $T$. armeniaca complex, we found that the songs of different individuals within the same population may vary to almost the same extent as in general (see Figs. 3 and 7). Rarely, single individuals may also produce a different song by alternating monosyllabic, disyllabic, or polysyllabic echemes within one performance (see Fig. 3 (5Ba, $\mathrm{Bb}, 9 \mathrm{~A}, 9 \mathrm{~B})$ ). The genetic structure also showed very low
Table 3 Net mean genetic distances (\%) within Tettigonia clades for mitochondrial (COI) and nuclear (ITS1 + ITS2) genes

\begin{tabular}{lll}
\hline & COI clades & ITS1 + ITS2 clades \\
\hline T. viridissima + T vaucheriana complex & 0.02 & 0.01 \\
T. uvarovi & - & - \\
T. armeniaca complex + T. caudata s. str. & 0.01 & 0.05 \\
T. caudata s. str. & 0 & 0.01 \\
T. cantans & 0 & 0.07 \\
\hline
\end{tabular}


Fig. 5 Appearance of some taxa of Western Palaearctic Tettigonia (relative size proportions between photos not retained). a $T$. cantans, male, Germany, Gunzenhausen; b T. cantans, female, Germany, Gunzenhausen; c T. uvarovi Ebner, 1946-male, holotype, Siberia (NHMW), lateral view; d same, dorsal view; e T. caudata, male, Bulgaria, Russe district, Byala; $\mathbf{f}$ T. acutipennis Ebner, 1946 - male, holotype, "Kleinasien 1914 | Marasch, Tölg. | coll. R. Ebner" (NHMW), dorsal view; g same, lateral view; h $T$. armeniaca, male, Armenia, Djermuk; i T. armeniaca, male, Turkey, Ispir; $\mathbf{j}$ T. viridissima morphotype of longealata, male, Morocco, El Kebab; k T. viridissima morphotype of longealata, female, Morocco, El Kebab; I T. viridissima morphotype of vaucheriana, male, Morocco, El Kebab; and m T. viridissima, male and female in copula, Bulgaria, Haskovo district, Kostilkovo village
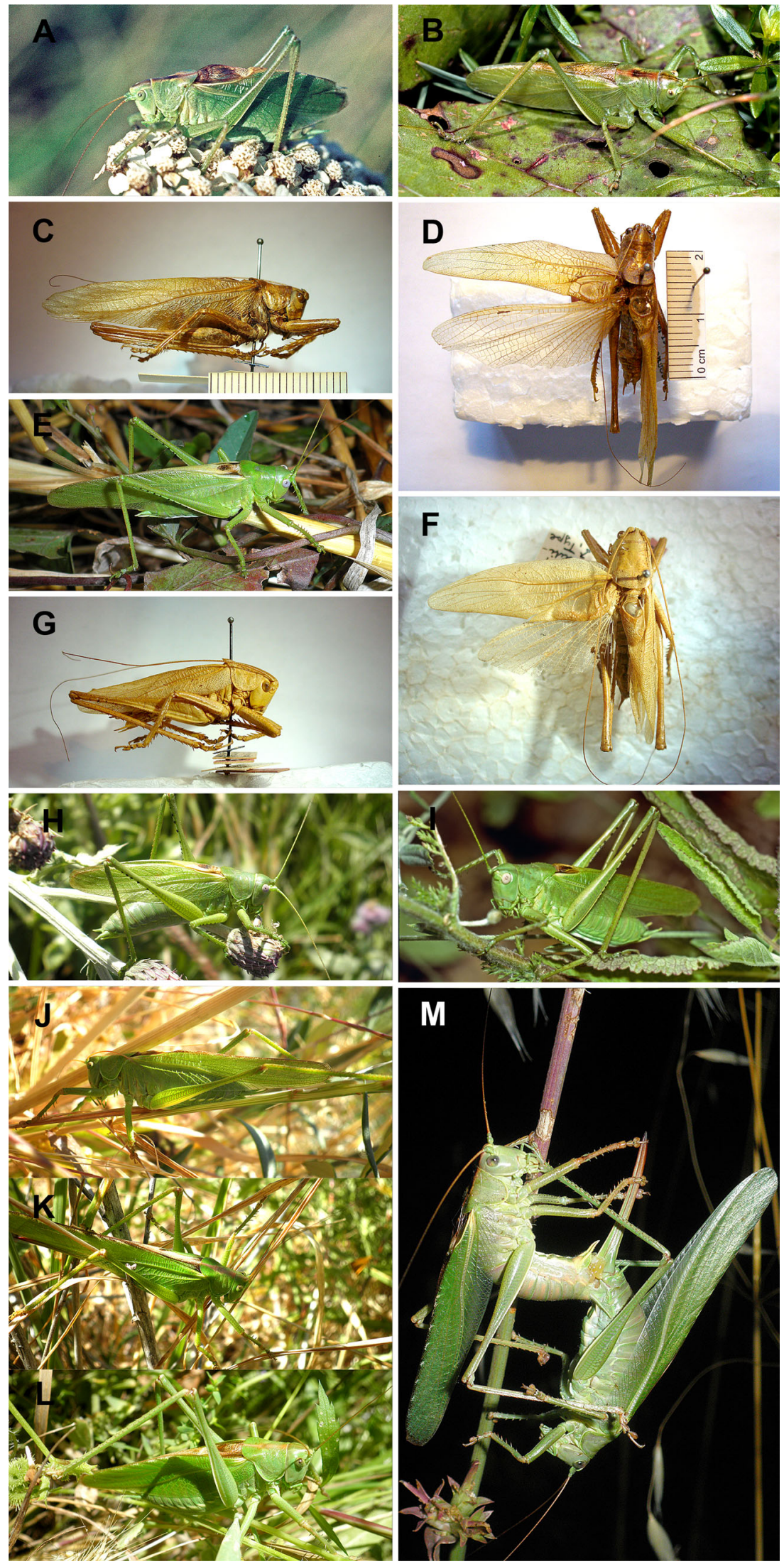

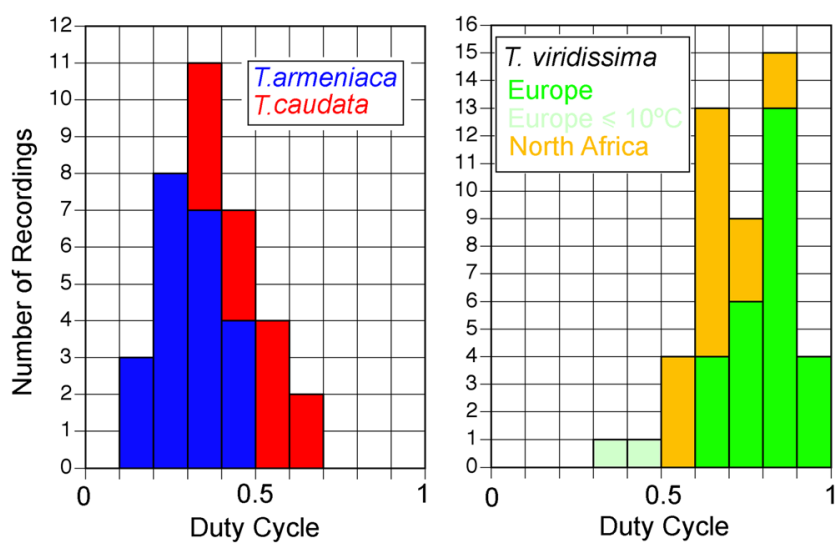

Fig. 6 Comparison of the duty cycle in the songs of the T. armeniaca complex and T. caudata (left panel) and the Tettigonia viridissima group (right panel)

(almost zero) differentiation for the COI fragment within the $T$. armeniaca complex, while distances within the clade consisting of the $T$. armeniaca complex and T. caudata were from very low (COI) to moderate (ITS) (Table 3).

Clade C (Fig. 4) is here represented by a single taxon, T. cantans (Fig. 5a, b). Its basal position in the tree supports the suggestion that its song corresponds to an ancestral state for Tettigonia due to its simple structure and low female preference towards temporal song parameters (Schul 1998).

\section{Discussion}

The genus Tettigonia is one of the ecologically most successful Palaearctic groups of bush-crickets, distributed throughout the Palaearctic ecozone. The Green Bush-crickets occur in a wide variety of habitats - from the semideserts of North Africa and Central Asia to Eurasian taiga and the lush meadows of the treeless mountain zone. The low mitochondrial genetic

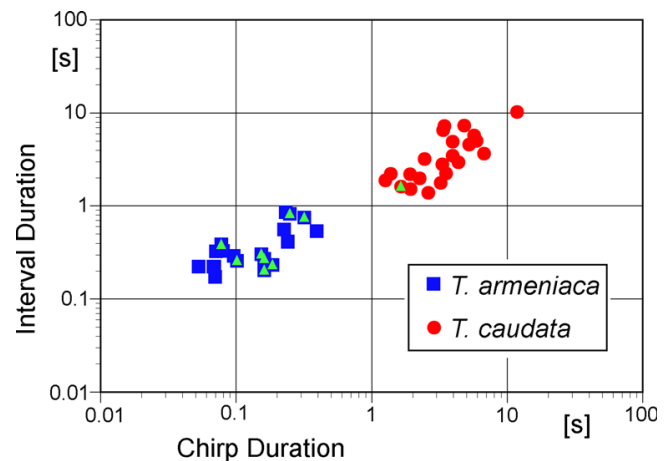

Fig. 7 Relationship between the duration of chirps and inter-chirp intervals in T. caudata and the Tettigonia armeniaca complex. Green triangles mark recordings from Ispir, Turkey, where monosyllabic, disyllabic, and polysyllabic songs of $T$. armeniaca were recorded, as well as a song of T. caudata (Color figure online) differentiation found in this study suggests relatively recent diversification and fast expansion throughout the Palaearctic and the occasional presence of hybrids, even between members of different clades (Schul 1995), are in support of the latter suggestion. The occurrence of the most basal branching resulting in the topology clade $\mathrm{C}($ T. cantans $)+($ clades $\mathrm{A}, \mathrm{B})$ supports the ancestral state of the temporal song structure and the low female preference filter of T. cantans (Schul 1998). Furthermore, this type of song (although female acoustic preference is not known) occurs in T. uvarovi, the basal taxon in clade B. Interestingly, T. uvarovi has relatively short wings but is similar in overall habitus to T. viridissima, which is another piece of evidence suggesting a closer relationship between clades A and B. While both T. cantans and T. uvarovi are typically found in humid habitats with a moderate to cool climate and occupy the northernmost areas of the range of this genus, $T$. caudata and the T. armeniaca complex occur mostly in mountainous and steppe areas from southeastern Europe, through Anatolia and Iran, to Central Asia. Thus, song elaboration by changes in syllable length and the development of echemes may have been connected with the southwestern expansion from the Eastern Palaearctic towards drier open habitats in the mountains of Central Asia and/or Irano-Anatolia.

The uniform morphology, intraindividual and intrapopulation song variability, and low genetic distances suggest that all studied members of the T. armeniaca complex represent a single taxonomic unit. The variable song pattern within the complex is a unique phenomenon in bush-crickets. The incorporation of either long monosyllables or short disyllabic or polysyllabic echemes in communication indicates an unusual mechanism of song recognition. The recognition mechanism of females of the related $T$. caudata requires mainly echemes that do not contain long intervals, i.e., echemes composed of a fast sequence of syllables (high syllable repetition rate; Schul 1998). Those females accept even continuous songs without intervals (Schul 1998). Yet, the minimum acceptable duration of an echeme has not been tested. Females of the T. armeniaca complex may use the same criterion, possibly accepting shorter echeme durations than $T$. caudata and rejecting longer ones. In this case, the internal structure of a chirp can vary as long as there are no long intervals within a chirp. Populations of the $T$. armeniaca complex occur sympatrically with T. caudata (their suspected syntopic occurrence may be marginal or accidental), and thus, low selectivity could provoke hybridization. Yet, we found neither significant differences in the song frequency (unpublished data) and duty cycle (Fig. 6), nor evidence for hybrids between these groups. Thus, to elucidate the mechanisms of recognition and sexual selection in this group, it is necessary to conduct large-scale population genetic research combined with a behavioral study of female acoustic preferences.

Clade A is composed of a group of populations with relatively uniform song patterns, more or less typical of 
T. viridissima. In contrast to the T. armeniaca complex discussed previously, here, a uniform song pattern was present within a rather wide range of morphotypes. However, variation concerned only body size and wing length, while the shape of the female external genitalia and the male internal and external genitalia did not differ across the morphotypes. Although the song pattern showed moderate geographical structuring (shorter echemes in North African populations), genetic data revealed a mixed pattern of all sampled populations. The duty cycle distribution (Fig. 6) largely overlapped between Eurasian and North African samples. The previous data suggest a recent expansion of $T$. viridissima populations to the African continent (possibly during the glacial maxima connected with the ocean level decreasing since the Pleistocene). Thus, isolated micropopulations may have specialized in certain microclimates prior to subsequent secondary contact and gene exchange. Similar morphological changes involving shorter wings have been observed in T. viridissima populations occurring in Great Britain (Cooper et al. 2012).

\section{Taxonomic reconsiderations}

Following the interdisciplinary study presented previously, we suggest the following taxonomic reconsiderations:

\section{T. viridissima (Linnaeus, 1758)}

T. vaucheriana Pictet, 1888, syn.n.

T. maroccana Bolívar, 1893, syn.n. (upon synonymy with T. vaucheriana)

T. lozanoi (Bolívar, 1914), syn.n.

T. longealata Chopard, 1937, syn.n.

T. krugeri Massa, 1998, syn.n.

Notes, diagnosis, and distribution In Northern Africa, two morphological groups of species occur. The Tettigonia savignyi group contains T. savignyi (Lucas, 1849) and Tettigonia macroxipha (Bolívar, 1914) (including also Tettigonia longispina Ingrisch, 1983, described from Sardinia) that characterizes with male cercus with a very big internal spine (longer than the width of cercus), titillators with short stout apical arms with a very small second apical hook and apically attenuated female subgenital plate with a narrow incision. This group has not been considered in the present study.

The second group involves species related to $T$. viridissima and here assigned to as $T$. vaucheriana complex (among the listed in Eades et al. 2016, valid taxa are T. vaucheriana, T. lozanoi, T. longealata, and T. krugeri). The latter characterizes with male cercus with a short internal spine (much shorter than the width of cercus), titillators with long gracile apical arms with two equal apical hooks, and apically widened female subgenital plate with a wide incision. Formerly, the latter taxa were considered distinct species on account of differences in the length of tegmina, body size, and width of scapus in relation to the first antennal segment and subtle differences in the female subgenital plate (based on dry specimens in which its shape may differ after deformation due to desiccation). With the present study, we found all these characters highly variable between and within populations. For example, width of scapus is in direct relation to the body size (the stouter the body is, the wider the scapus is in relation to the first antennal segment). Considering the low genetic distances, uniform male and female genitalia, and the uniform song of the studied populations subjectively referred to at least three of the mentioned taxa, we consider all members of the $T$. vaucheriana complex synonymous with $T$. viridissima. Thus, the species distribution, known to be mostly restricted north of the Mediterranean, is now proved to cover all Western Palaearctic including the southern Mediterranean on the territories of northern Morocco, Algeria, and partly Libya (thus, without any doubt, also Tunisia).

T. armeniaca Tarbinsky, 1940, stat. nov.

T. acutipennis Ebner, 1946, syn.n.

T. turcica Ramme, 1951, syn.n.

Notes, diagnosis, and distribution Two species related to T. caudata and usually recognized by their shorter wings are known to occur in Anatolia (T. acutipennis and T. turcica) (Ebner 1946; Ramme 1951). Similarly to T. caudata, these taxa are characterized by well-visible black dots in the base of the ventral spines of the femora (most visible in the apical half of hind femora), strongly apically attenuated stridulatory file, long ovipositor (as long as or longer than body, while shorter in most other Tettigonia), short and apically outcurved male cerci, and male titillators with comparatively stout apical arms ending with two short hooks. T. acutipennis and T. turcica differ from T. caudata by the shorter (usually less than $33 \mathrm{~mm}$, while over 33 in T. caudata) and apically tapering tegmina, shorter hind femora (usually less than $25 \mathrm{~mm}$, while over 25 in T. caudata), and less expressed black dots ventrally on the femora. From the Caucasus area, the subspecies $T$. caudata armeniaca has been described by Tarbinsky (1940) and later synonymized with T. caudata caudata by Stolyarov (1983). Our samples showed that the morphotype of $T$. armeniaca complex is widely distributed in the Transcaucasus area. Summarizing the results of the current study, we prove that $T$. armeniaca complex represents a single well-outlined species, $T$. armeniaca, stat. nov., with two newly established synonyms, T. acutipennis, syn.n., and T. turcica, syn.n. T. armeniaca characterizes with the previously mentioned features, as well as by its unique variable song and low genetic distances between its populations. Acoustically, it differs from T. caudata by the shorter chirps (echemes) and chirp intervals, both being less than a second, while over $1 \mathrm{~s}$ in T. caudata.

T. armeniaca occurs in moderately humid grass and shrub associations in the high plateaus and mountains of Eastern 
Anatolia and whole Transcaucasia (Georgia, Armenia, and Azerbaijan), as well as in the Northern Iran (at least in the Elburs range) (this study and own unpublished data). Its occurrence further east in the mountains of Central Asia is not excluded.

\section{Conclusions}

The taxonomy of Tettigonia was hitherto based only on morphological descriptions that frequently led to difficulties in outlining its systematics and relationships between taxa (see references in the "Introduction" section). In the present study, we partially revealed the phylogeny and relationships of the genus Tettigonia, with a focus on the major groups in the Continental Palaearctic. Three main lineages were outlined representing three distinct clades with unique morpho-acoustic evolution. The combination of variable morphology and uniform song in the T. viridissima lineage, and of variable song and uniform morphology in the T. caudata/armeniaca lineage, addressed a multitude of evolutionary and behavioral questions. This paper provides a foundation for future investigations into the evolution of the recognition mechanisms and female choice in Tettigonia, which led to this diversity of forms, being the cause or result of the ecological success of Green Bush-crickets.

Acknowledgements We kindly acknowledge the collectors who donated material for this study, namely, Roman Babko, Pedro J. Cordero, Tomasz Postawa, Gellért Puskas, Sergey Storozhenko, and Bogdan Wiśniowski. We are grateful to the late Fer Willemse, who provided copies of his sound recordings. This study was supported by grant 2011/01/B/NZ8/01467 from the National Science Centre, Poland (B. Grzywacz). T. Karamysheva was partially supported by The Russian Foundation for Basic Research, research project no. 14-04-00086a. The morphological studies on additional historic material of Tettigonia (Naturhistorisches Museum, Vienna; the Natural History Museum, London; the Hungarian Natural History Museum, Budapest) were possible by the financial support of the SYNTHESYS (European Commission's Research Infrastructures Network funded under FP7) grants AT-TAF-546, GB-TAF-1320, and HU-TAF-2202 to D. Chobanov.

Open Access This article is distributed under the terms of the Creative Commons Attribution 4.0 International License (http:// creativecommons.org/licenses/by/4.0/), which permits unrestricted use, distribution, and reproduction in any medium, provided you give appropriate credit to the original author(s) and the source, provide a link to the Creative Commons license, and indicate if changes were made.

\section{References}

Akaike, H. (1974). A new look at the statistical model identification. IEEE Transactions on Automatic Control, 19(6), 716-723.

Allegrucci, G., Trucchi, E., \& Sbordoni, V. (2011). Tempo and mode of species diversification in Dolichopoda cave crickets (Orthoptera, Rhaphidophoridae). Molecular Phylogenetics and Evolution, 60, $108-121$.
Audacity team (1999-2013). Audacity 2.0.3. Audacity 2.0.3, http://web. audacityteam.org/.

Barataud, M. (2007). Sauterelles de France. Edition Sitelle. Compact Disc.

Bellmann, H. (2004). Heuschrecken. Edition Ample, Germering. Compact Disc.

Bolívar, I. (1914). Dermapteros y Ortopteros de Marruecos. Memorias de la Real Sociedad Española de Historia Natural, 8, 157-239.

Bonnet, F. R. (1995). Guide sonore des sauturelles, grillons et criquets d'Europe occidentale. Compact Disc. Lausanne and Paris: Delachaux and Niestle.

Boztepe, Z., Kaya, S., \& Çıplak, B. (2013). Integrated systematics of the Poecilimon luschani species group (Orthoptera, Tettigoniidae): radiation as a chain of populations in a small heterogeneous area. Zoological Journal of the Linnean Society, 169, 43-69.

Chapco, W., \& Litzenberger, G. (2002). A molecular phylogenetic analysis of the grasshopper genus Melanoplus Stal (Orthoptera: Acrididae). An update. Journal of Orthoptera Research, 11, 1-9.

Chobanov, D. P., \& Heller, K.-G. (2010). Revision of the Poecilimon ornatus group (Orthoptera: Phaneropteridae) with focus on Bulgaria and Macedonia. European Journal of Entomology, 107, 647-672.

Chobanov, D. P., Lemonnier-Darcemont, M., Darcemont, C., Puskás, G., \& Heller, K.-G. (2014). Tettigonia balcanica, a new species from the Balkan Peninsula (Orthoptera, Tettigoniidae). Entomologia, 2(2), 209, 95-209,106.

Chopard, L. (1943). Orthoptèroïdes de l'Afrique du Nord. Faune de l'Empire Français. Librairie Larose II, Paris (p. 447).

Çıplak, B., Heller, K.-G., \& Willemse, F. (2009). Review of the genus Eupholidoptera (Orthoptera, Tettigoniidae): different genitalia, uniform song. Zootaxa, 2156, 1-77.

Çiplak, B., Kaya, S., Boztepe, Z., \& Gunduz, I. (2015). Mountainous genus Anterastes (Orthoptera, Tettigoniidae): autochthonous survival in refugial habitats across several glacial ages via vertical range shifts. Zoologica Scripta, 44, 534-549.

Cooper, E. M., Lunt, P. H., Ellis, J. S., \& Knight, M. E. (2012). Biogeographical patterns of variation in Western European populations of the great green bush-cricket (Tettigonia viridissima; Orthoptera Tettigoniidae). Journal of Insect Conservation, 17(3), 431-440.

Cooper, S. J., Ibrahim, K. M., \& Hewitt, G. M. (1995). Postglacial expansion and genome subdivision in the European grasshopper Chorthippus parallelus. Molecular Ecology, 4, 49-60.

Eades, D. C., Otte, D., Cigliano, M. M., \& Braun, H. (2016). Orthoptera Species File Online. Version 5.0/5.0. (24/5/2016) http://Orthoptera. SpeciesFile.org.

Ebner, R. (1946). Einige seltenere paläarktische Tettigoniidae und Gryllidae (Orthoptera). Eos-Revista Española de Entomologia, 22, $17-30$.

Edgar, R. C. (2004). MUSCLE: multiple sequence alignment with high accuracy and high throughput. Nucleic Acids Research, 32(5), 1792-1797.

Fan, B.-F., Wang, J., \& Lu, R.-S. (2013). Comparative study on male songs of four species of Tettigoniidae in Xinjiang. Acta Zootaxonomica Sinica, 38(2), 239-245.

Folmer, O., Black, M., Hoeh, W., Lutz, R., \& Vrijenhoek, R. (1994). DNA primers for amplification of mitochondrial cytochrome c oxidase subunit I from diverse metazoan invertebrates. Molecular Marine Biology and Biotechnology, 3(5), 294-299.

Gomboc, S., \& Segula, B. (2014). Pojoce kobilice Slovenije/Singing Orthoptera of Slovenia. EGEA, Zavod za naravo, Ljubljana: 1240. + Compact Disc.

Gorochov, A. V. (1995). System and evolution of the suborder Ensifera (Orthoptera). II. Proceedings of the Zoological Institute, Russian Academy of Sciences, 260, 212 (in Russian, English summary) 
Grein, G. (ed) (1984). Gesänge der einheimischen Heuschrecken. Deutscher Jugendbund für Naturbeobachtung and Niedersächsisches Landesverwaltungamt, Hannover. Long-playing record and booklet (2001 on Compact Disc).

Guindon, S., \& Gascuel, O. (2003). A simple, fast and accurate algorithm to estimate large phylogenies by maximum likelihood. Systematic Biology, 52, 696-704.

Harz, K. (1969). Die Orthopteren Europas/the Orthoptera of Europe. Vol. I. Series Entomologica, 5, 749.

Heller, K.-G. (1988). Bioakustik der Europäischen Laubheuschrecken. Ökologie in Forschung und Anwendung 1. Josef Margraf (p. 358).

Heller, K.-G. (1990). Evolution of song pattern in east Mediterranean Phaneropterinae: constraints by the communication system. In W. J. Bailey \& D. C. F. Rentz (Eds.), The Tettigoniidae: biology, systematics and evolution (pp. 130-151). Berlin: Crawford House Press, Bathurst and Springer.

Heller, K.-G. (2006). Song evolution and speciation in bushcrickets. In S. Drosopoulos \& M. F. Claridge (Eds.), Insect sounds and communication, physiology, behaviour, ecology and evolution (pp. 207-219). Boca Raton: CRC Press.

Hochkirch, A., \& Lemke, I. (2011). Asymmetric mate choice, hybridization, and hybrid fitness in two sympatric grasshopper species. Behavioral Ecology and Sociobiology, 65, 1637-1645.

Huelsenbeck, J. P., \& Ronquist, F. (2001). MRBAYES: Bayesian inference of phylogeny. Bioinformatics, 17, 754-755.

Huelsenbeck, J. P., Ronquist, F., Nielsen, R., \& Bollback, J. P. (2001). Bayesian inference of phylogeny and its impact on evolutionary biology. Science, 294, 2310-2314.

Ichikawa, A., Kano, Y., Kawai, M., Tominago, O., \& Murai, T. (2006). Orthoptera of the Japanese Archipelago in Color (pp. $687+$ CD). Japan, Hokkaido: Hokkaido University (Orthopterological Society of Japan), (in Japanese).

Kim, T. W. (2009). Taxonomy and acoustic signals of Korean Tettigonioidea (Orthoptera: Ensifera) (II). Incheon: NIBR (National Institute Biological Resources), (pp. $140+\mathrm{CD}$ ) (in Korean).

Kim, T.-K., Han, T., Kim, T.-W., Park, I. G., Kim, S., \& Park, H. (2016). A molecular phylogenetic study on South Korean Tettigonia species (Orthoptera: Tettigoniidae) using five genetic loci: the possibility of multiple allopatric speciation. Zootaxa, 4092(2), 219-230.

Kleukers, R. M. J. C., van Nieukerken, E., Odé, B., Willemse, L., \& van Wingerden, W. (1997). [The grasshoppers and crickets of the Netherlands (Orthoptera).] De sprinkhanen en krekels van Nederland (Orthoptera). Knnv Uitgeverij, Utrecht. Nederlandse Fauna, Deel 1. + Compact Disc by Odé B.

Kocarek, P., Holusa, J., Vlk, R., \& Marhoul, P. (2013). Rovnokridli Ceske republiky (Insecta: Orthoptera) (pp. 1-285. + Compact Disc). Czech Republic: Academia, Praha.

Massa, B. (1998). Attuali conoscenze sugli Ortotteri della Libia (Insecta Orthoptera). Il Naturalisto Siciliano, 4(22), 235-320.

Massa, B., Fontana, P., Buzetti, F. M., Kleukers, R., \& Odé, B. (2012). Orthoptera. In: Fauna d'Italia 48 (p. 563). Calderini, Milano.

Nielsen, F. O. (2000). De Danske Graeshopper. Stenstrup: Apollo Books (pp. 1-192. + Compact Disc).

Nylander, J. A. A. (2004). MrModeltest v2. Program distributed by the author. Evolutionary Biology Centre, Uppsala University, Uppsala, Sweden.

Odé, B., \& Fontana, P. (2002). Grasshoppers and crickets of the Veneto region. Sound guide. Museo Naturalistico Archaeologico Di Vicenza, Vicenza. Compact Disc.

Ogawa, J. (2003). A new species of the genus Tettigonia from Tsushima Is. of Japan (Orthoptera, Tettigoniidae). Japanese Journal of Systematic Entomology, 9(2), 291-295.

Page, R. D. M. (1996). TreeView: an application to display phylogenetic trees on personal computers. Computer Applications in the Biosciences, 12, 357-358.

Paterson, H. E. H. (1985). The recognition concept of species. In E. S. Vrba (Ed.), Species and speciation (pp. 21-29). Pretoria: Transvaal Museum.
Pettersson Electronics and Acoustics AB (1996-2010). BatSound 4.1.4. http://www.batsound.com/?p=15.

Pinedo, C. (1985). Los Tettigoniidae de la Peninsula Ibérica, España insular y norte de Africa. Eos, 61, 241-263.

Ragge, D. R., \& Reynolds, W. J. (1998). The songs of the grasshoppers and crickets of western Europe. Harley Books, Colchester, Essex. 1998: I-X, 1-591. + Compact Disc.

Rambaut, A. (2008). FigTree v1.1.1: tree figure drawing tool. Available: http://tree.bio.ed.ac.uk/software/figtree/. Accessed 20 June 2008.

Rambaut, A., \& Drummond, A. J. (2007). Tracer v1.4: MCMC trace analyses tool. Available: http://beast.bio.ed.ac.uk/Tracer.

Ramme, W. (1951). Zur Systematik, Faunistik und Biologie der Orthopteren von Südost-Europa und Vorderasien. Mitteilungen aus dem Zoologischen Museum in Berlin, 27, 1-432.

Rhee, H. (2013). Disentangling the distribution of Tettigonia viridissima (Linnaeus, 1758) in the eastern part of Eurasia using acoustical and morphological data. Articulata, 28(1/2), 103-114.

Roesti, C., \& Keist, B. (2009). Die Stimmen der Heuschrecken. Haupt Verlag; Bern, Stuttgart, Wien. 1-144. + DVD.

Schul, J. (1994). Untersuchungen zur akustischen Kommunikation bei drei Arten der Gattung Tettigonia (Orthoptera, Tettigoniidae). PhD Thesis, Marburg.

Schul, J. (1995). A case of interspecific hybridization in the genus Tettigonia (Saltatoria: Ensifera). Entomologia Generalis, 19(3), 185-190.

Schul, J. (1998). Song recognition by temporal cues in a group of closely related bushcricket species (genus Tettigonia). Journal of Comparative Physiology A, 183, 401-410.

Schul, J., von Helversen, D., \& Weber, T. (1998). Selective phonotaxis in Tettigonia cantans and T. viridissima in song definition and discrimination. Journal of Comparative Physiology A, 182, 687-694.

Swofford, D. L. (2002). PAUP*. Phylogenetic Analysis Using Parsimony (*and other methods). Version 4.0b10a. Sinauer Associates, Sunderland, Massachusetts.

Song, H., Amédégnato, C., Cigliano, M. M., Desutter-Grandcolas, L., Heads, S. W., Huang, Y., Otte, D., \& Whiting, M. F. (2015). 300 million years of diversification: elucidating the patterns of orthopteran evolution based on comprehensive taxon and gene sampling. Cladistics, pp. 1-31.

Stolyarov, M. V. (1983). Taxonomic remarks on some Orthoptera of the Caucasus. Vestnik Zoologii, 3, 15-21 (in Russian, English abstract).

Storozhenko, S. Yu., Kim, T.-W., \& Jeon, M. J. (2015). Monograph of Korean Orthoptera. Incheon: National Institute of Biological Resources.

SYSTAX (2015). SysTax - a database system for systematics and taxonomy http://www.biologie.uni-ulm.de/systax/daten/index.html (May 01, 2015).

Tamura, K., Stecher, G., Peterson, D., Filipski, A., \& Kumar, S. (2013). MEGA6: Molecular Evolutionary Genetics Analysis version 6.0. Molecular Biology and Evolution, 30, 2725-2729.

Tarbinsky, S. P. (1940). [The saltatorian orthopterous insects of the Azerbaidzhan SSR] (p. 245). Moscow-Leningrad: Acad. Sci. Azyerbaidjandkoi S.S.R. (in Russian).

Ullrich, B., Reinhold, K., Niehuis, O., \& Misof, B. (2010). Secondary structure and phylogenetic analysis of the internal transcribed spacers 1 and 2 of bush crickets (Orthoptera: Tettigoniidae: Barbitistini). Journal of Zoological Systematics and Evolutionary Research, 48(3), 219-228.

Weekers, P. H. H., De Jonckheere, J. F., \& Dumont, H. J. (2001). Phylogenetic relationships inferred from ribosomal ITS sequences and biogeographic patterns in representatives of the genus Calopteryx (Insecta: Odonata) of the West Mediterranean and adjacent West European zone. Molecular Phylogenetics and Evolution, 20, 89-99.

Zhantiev, R. D., \& Korsunovskaya, O. S. (1978). Morphofunctional organization of tympanal organs in Tettigonia cantans. Zoologiceskij Zhurnal, 57, 1012-1016 (in Russian). 